\title{
Anti-pathogenic potential of a classical ayurvedic formulation-
}

\section{Triphala [version 1; peer review: 2 approved with reservations]}

\author{
Hinal Patel, Foram Patel (D), Vinit Jani (D), Neha Jha, Afsa Ansari, Bhumika Paliwal, \\ Bharatsingh Rathod, Dhruvi Patel, Pooja Patel (D), Vijay Kothari(D)
}

Institute of Science, Nirma University, Ahmedabad, Gujarat, 382481, India

V1 First published: 18 Jul 2019, 8:1126

https://doi.org/10.12688/f1000research.19787.1

Latest published: 01 Oct 2020, 8:1126

https://doi.org/10.12688/f1000research.19787.2

\section{Abstract}

A classical ayurvedic polyherbal formulation namely Triphala was assessed for its anti-pathogenic potential against five different pathogenic bacteria. Virulence of four of them towards the model host Caenorhabditis elegans was attenuated (by 18-45\%) owing to pretreatment with Triphala $(\leq 20 \mu \mathrm{g} / \mathrm{ml})$. Triphala could also exert significant therapeutic effect on worms already infected with Chromobacterium violaceum, Serratia marcescens or Staphylococcus aureus. Prophylactic use of Triphala allowed worms to score 14-41\% better survival in face of subsequent pathogen challenge. Repeated exposure to this formulation induced resistance in $S$. marcescens, but not in $P$. aeruginosa. It also exerted a post-extract effect (PEE) on three of the test pathogens. Triphala was able to modulate production of quorum sensing (QS)-regulated pigments in three of the multidrugresistant gram-negative test bacteria. Haemolytic activity of $S$. aureus was heavily inhibited under the influence of this formulation. $P$. aeruginosa's lysozyme-susceptibility was found to increase by $\sim 25-43 \%$ upon Triphala-pretreatment. These results validate therapeutic potential of one of the most widely used polyherbal ayurvedic formulations called Triphala.

\section{Keywords}

Antimicrobial resistance (AMR), Quorum Sensing (QS), Triphala, Polyherbal, Post Extract Effect (PEE), Anti-virulence, Lysozyme

\section{Open Peer Review \\ Approval Status \\ 1 \\ 2 \\ version 2 \\ (revision) \\ 01 Oct 2020 \\ version 1 \\ 18 Jul 2019

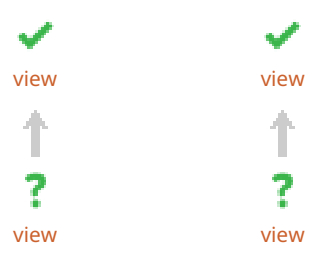 \\ 1. Shibabrata Pattanayak ID, Government of \\ West Bengal, Kolkata, India \\ 2. Felipe Alves de Almeida (D), Federal \\ University of Juiz de Fora (UFJF), Governador \\ Valadares, Brazil \\ Any reports and responses or comments on the article can be found at the end of the article.}

This article is included in the Pathogens gateway. 


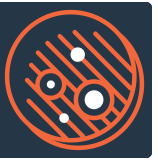

This article is included in the Antimicrobial

Resistance collection.

Corresponding author: Vijay Kothari (vijay.kothari@nirmauni.ac.in)

Author roles: Patel H: Data Curation, Investigation, Writing - Original Draft Preparation, Writing - Review \& Editing; Patel F: Data Curation, Investigation, Writing - Original Draft Preparation, Writing - Review \& Editing; Jani V: Data Curation, Investigation; Jha N: Investigation; Ansari A: Investigation; Paliwal B: Investigation; Rathod B: Investigation; Patel D: Investigation; Patel P: Data Curation, Investigation, Validation, Writing - Original Draft Preparation, Writing - Review \& Editing; Kothari V: Conceptualization, Data Curation, Formal Analysis, Funding Acquisition, Methodology, Project Administration, Resources, Supervision, Visualization, Writing - Original Draft Preparation, Writing - Review \& Editing

Competing interests: No competing interests were disclosed.

Grant information: This work was supported by Nirma Education \& Research Foundation (NERF)

The funders had no role in study design, data collection and analysis, decision to publish, or preparation of the manuscript.

Copyright: ( $) 2019$ Patel $\mathrm{H}$ et al. This is an open access article distributed under the terms of the Creative Commons Attribution License, which permits unrestricted use, distribution, and reproduction in any medium, provided the original work is properly cited.

How to cite this article: Patel $\mathrm{H}$, Patel F, Jani $\mathrm{V}$ et al. Anti-pathogenic potential of a classical ayurvedic formulation- Triphala [version 1; peer review: 2 approved with reservations] F1000Research 2019, 8:1126 https://doi.org/10.12688/f1000research.19787.1

First published: $18 \mathrm{Jul}$ 2019, 8:1126 https://doi.org/10.12688/f1000research.19787.1 


\section{Background}

Antibiotic-resistant bacterial infections are among the most serious public-health threats. Since the emergence and spread of antimicrobial resistance (AMR) is shrinking the utility spectrum of conventional bactericidal antibiotics, there is an urgent need for discovery and development of novel anti-virulence formulations. Traditional Medicine (TM) systems like Ayurveda offer several sophisticated formulations for a variety of disease conditions. One such classical ayurvedic formulation with a long history of safe use is Triphala. Triphala is a polyherbal formulation containing three myrobalans fruits i.e. Phyllanthus emblica, Terminalia chebula, and Terminalia bellerica (Patwardhan et al., 2015). Triphala is prescribed as a general health promoter, for management of metabolic disorders, dental and skin problems, and for wound management. It has been reported to be active against bacterial pathogens of urinary tract (Bag et al., 2013), and as an anticaries agent for control of gum infections (Bhattacharjee et al., 2015; Prakash \& Shelke, 2014). Though many popular formulations like Triphala have been used historically in TM and as a household remedy, their validation through modern scientific methods is necessary for their wider acceptance in modern medicine (Kothari, 2018). This study aimed to investigate the anti-pathogenic efficacy of Triphala against five different pathogenic bacteria.

\section{Methods}

Test formulation

Triphala formulation (TF) (Emami Ltd; batch no. EM0029; Proportion of 3 constituent plant species: 1:1:1) was purchased from a local market. For assay purpose, $150 \mathrm{mg}$ of this formulation was suspended in $5 \mathrm{ml}$ of DMSO (Merck, Mumbai), followed by vortexing for $15 \mathrm{~min}$. Then it was centrifuged at $8,000 \mathrm{rpm}$ for $30 \mathrm{~min}$ at ambient temperature, and resulting supernatant was collected in a sterile glass vial $(15 \mathrm{ml}$; Borosil) and stored under refrigeration till further use. Remaining pellet was subjected to drying in an oven at $70-80^{\circ} \mathrm{C}$ until the solvent was completely evaporated, followed by weighing of the dried plant material. Subtracting the latter from the initial weight of $150 \mathrm{mg}$, the concentration of test formulation in supernatant was calculated to be $22.94 \mathrm{mg} / \mathrm{ml}$. This way the whole formulation was found to contain $70 \%$ DMSO soluble fraction, which was used for our experiments.

\section{Bacterial strains}

Chromobacterium violaceum (MTCC 2656), Serratia marcescens (MTCC 97), Staphylococcus aureus (MTCC 737), and Streptococcus pyogenes (MTCC 1924) were procured from Microbial Type Culture Collection (MTCC), Chandigarh. Pseudomonas aeruginosa was available in our institutional culture collection. All the three gram-negative bacteria used in this study were multidrug resistant, and their antibiogram has previously been reported by us (Joshi et al., 2019; Patel et al., 2019a). Additionally, C. violaceum and S. marcescens strains mentioned here have been reported by us as beta-lactamase producers (Sarvaiya \& Kothari, 2017).

\section{In vivo assays}

In vivo efficacy of Triphala against bacterial infections was tested in the nematode host Caenorhabditis elegans (N2-Bristol strain; maintained at the Institute of Science, Nirma University).
Maintenance and synchronization of the worm population was done as previously described in Joshi (2019). Worms were maintained on NGM [Nematode Growing Medium; $2.5 \mathrm{~g} / \mathrm{L}$ peptone (HiMedia, RM001-500G), $3 \mathrm{~g} / \mathrm{L} \mathrm{NaCl}$ (HiMedia, MB023-500G), 1 M CaCl (HiMedia, GRM534-500G), $1 \mathrm{M}$ $\mathrm{MgSO}_{4}$ (Merck, 1.93645.0521), $5 \mathrm{mg} / \mathrm{mL}$ cholesterol (HiMedia, TC101-5G), $1 \mathrm{M}$ phosphate buffer of $\mathrm{pH} 6,17 \mathrm{~g} / \mathrm{L}$ agar-agar (HiMedia, GRM666-500G)] agar plate with E. coli OP50 (LabTIE B.V. OP50 V.2; batch \# 002, JR Rosmalen, the Netherlands) as food. For synchronization of the worm population, adult worms from a 4-5 days old NGM plate were first washed with distilled water, and then treated with $1 \mathrm{~mL}$ of bleaching solution [1N NaOH (HiMedia MB095-100G) $+4 \%$ $\mathrm{NaOCl}$ (Merck 61842010001730) + water in 1:1:3 proportion], followed by centrifugation $\left(22^{\circ} \mathrm{C} ; 1,500 \mathrm{rpm}\right)$ for $1 \mathrm{~min}$. Eggs in the resultant pellet were washed with sterile distilled water, and then transferred onto a new NGM plate seeded with $E$. coli OP50. L3-L4 stage worms appearing on this plate after 2-3 days of incubation at $22^{\circ} \mathrm{C}$ were used for further experiments.

Three different types of in vivo assays were done as under, employing the methodology described in reference cited in parenthesis following the assay name:

Anti-infective assay (Patel et al., 2018a): Triphala exposedpathogenic bacteria were allowed to infect $C$. elegans (L3-L4 stage), and their capacity to kill the worm population was compared with their Triphala-unexposed counterparts, over a period of 5 days.

Prophylactic assay (Patel et al., 2018b): Triphala-fed worms were challenged with pathogenic bacteria (previously not exposed to the test formulation), and their ability to survive in face of pathogen challenge was compared with their Triphala-unfed counterparts. C. elegans worms maintained on NGM were kept unfed for $24 \mathrm{~h}$ prior to being used for experiments. These worms were then fed with TF by mixing required concentration of this formulation $(100 \mu \mathrm{L})$ with $\mathrm{M} 9$ medium $(800 \mu \mathrm{L})$ and placed in a 24-well plate (non-treated polystyrene plates, sterile; HiMediaTPG24-1X50NO) containing 10 worms per well. Duration of exposure of worms to TF was kept to $96 \mathrm{~h}$, followed by addition of pathogenic bacteria $(100 \mu \mathrm{L}$ of bacterial suspension with $\mathrm{OD}_{764}=1.50$ measured with Agilent Cary 60 UV-Vis spectrophotometer). Appropriate controls i.e. worms previously not exposed to TF, but exposed to pathogenic bacteria; worms exposed neither to TF nor bacteria; and worms exposed to TF, but not to bacterial pathogens, were also included in the experiment. Incubation was carried out at $22^{\circ} \mathrm{C}$. Number of dead vs. live worms were counted every day for 5 days by putting the plate (with lid) under a light microscope (4X; Catalyst Biotech CatScope CS-U207T). Straight worms were considered to be dead. Plates were gently tapped to confirm lack of movement in the apparently-dead worms. On the last day of the experiment, when plates could be opened, their death was also confirmed by touching them with a straight wire, wherein no movement was taken as confirmation of death.

Triphala as a post-infection therapy (Patel et al., 2019b): Worms already infected with pathogenic bacteria (not previously exposed to the test formulation) were treated with Triphala 
to see whether the test formulation can exert any therapeutic effect on already infected worms. Assay methods remained the same as described in previous section, except that TF was added into assay wells after allowing bacteria either for $6 \mathrm{~h}$ or $24 \mathrm{~h}$ to establish infection.

Catechin (Sigma Aldrich; C1251-5G) and standard antibiotics (HiMedia; Ampicillin CMS645-1G; Gentamicin TC026-1G; Chloramphenicol CMS218-5G; Vancomycin CMS217-500MG) were used as positive controls. Catechin was employed at $100 \mu \mathrm{g} / \mathrm{ml}$, whereas different sub-MIC concentrations $(0.1-5 \mu \mathrm{g} / \mathrm{ml})$ of the antibiotics were used against different organisms as per their susceptibility.

Videos of some of the in vivo assays were captured on the fifth day of the experiment, using an inverted microscope (Nikon Eclipse Ti) under $4 \mathrm{X}$ objective lens, wherein $100 \mu \mathrm{l}$ of the liquid content from 24-well assay plate was transferred onto a large cover slip for observation and video capturing [see extended data (Patel et al., 2019c)].

\section{In vitro assays}

After confirming the in vivo anti-pathogenic efficacy of the Triphala formulation, we performed following in vitro assays to gain insight into interaction of this formulation with the pathogenic bacteria, as per the methodology described in respective references mentioned in the parenthesis:

a. Broth dilution assay (Joshi et al., 2016) to investigate effect of Triphala on bacterial growth and quorum sensing (QS)-regulated pigment production: C. violaceum, and $S$. marcescens were inoculated in nutrient broth (HiMedia MV002-500G) supplemented with TF. Media used for $S$. aureus and $P$. aeruginosa were Staphylococcus broth (HiMedia M578-500G) and Pseudomonas broth $[10 \mathrm{~g} / \mathrm{l}$ potassium sulfate (SRL 44277), $1.4 \mathrm{~g} / \mathrm{l}$ magnesium chloride (Merck 1.9366.30521), $16 \mathrm{~g} / \mathrm{l}$ peptone (HiMedia RM001-500G)] respectively. $S$. pyogenes was grown in BHI (brain heart infusion; HiMedia MV210-500G) broth. Following incubation, cell density was measured at $750 \mathrm{~nm}$ (Biorad 680). Pigment from these culture broths were extracted as previously described by us in Joshi et al. (2016). Cell pellets of $C$. violaceum, $S$. marcescens, and $S$. aureus were dissolved in DMSO [(Merck 1.07046.2521), acidified methanol [4 $\mathrm{ml} \mathrm{HCl}$ (HiMedia AS003$500 \mathrm{ML}$ ) into $96 \mathrm{ml}$ of methanol], and methanol (Merck 1.94516.2521) respectively. This allowed their pigments to be extracted in the solvent applied. In case of P. aeruginosa, pigment extraction was achieved by mixing chloroform (Merck 1.67024.0521) with culture broth (2:1 ratio). Quantification of each pigment was done at the wavelength nearest to its $\lambda_{\max }$, available in the microplate reader (Biorad 680) used by us.

b. Effect of Triphala on biofilm formation and its possible potential to eradicate pre-formed biofilm was assessed through crystal violet assay (Patel et al., 2013); and its effect on biofilm viability was assessed through MTT assay (Trafny et al., 2013). For the crystal violet assay, the biofilm-containing tubes (after discarding the inside liquid) were washed with PBS in order to remove all nonadherent bacteria and air-dried for $15 \mathrm{~min}$. Then, each of the washed tubes was stained with $1.5 \mathrm{~mL}$ of aqueous crystal violet solution $(0.4 \%$; SRL 54862-9) for $30 \mathrm{~min}$. Afterwards, each tube was washed twice with $2 \mathrm{ml}$ of sterile distilled water and immediately destained with $1500 \mu \mathrm{L}$ of ethanol (95\%). After $45 \mathrm{~min}$ of destaining, $1 \mathrm{~mL}$ of destaining solution was transferred into separate tubes and read at $570 \mathrm{~nm}$ (Biorad 680). For the MTT assay, the biofilmcontaining tubes (after discarding the inside liquid) were washed with PBS in order to remove all nonadherent bacteria and air-dried for $15 \mathrm{~min}$. Then, $900 \mu \mathrm{L}$ of minimal media was added into each tube, followed by addition of $100 \mu \mathrm{L}$ of $0.3 \%$ MTT (3-(4,5-dimethylthiazol-2-yl)-2,5-diphenyltetrazolium bromide; HiMedia MB186-100MG). After $2 \mathrm{~h}$ incubation at $37^{\circ} \mathrm{C}$, resulting purple formazan derivatives were dissolved in DMSO and measured at $570 \mathrm{~nm}$ (Biorad 680).

c. Effect of Triphala on haemolytic potential of the test pathogens (Neun et al., 2015): Small volume of human blood required for this assay was obtained from the authors, who each gave their written informed consent. The use of this blood was approved by the Institutional Ethics Committee of the Institute of Science, Nirma University (approval no: EC/NU/18/IS/4). Blood collection was executed by one of the authors (AA) on three different times in heparinized vials. $\mathrm{OD}_{750}$ of the overnight grown (in presence or absence of TF) culture was standardized to 1.00. Cell-free supernatant was prepared by centrifugation at $15,300 \mathrm{~g}$ for $10 \mathrm{~min} .10 \mu \mathrm{l}$ of human blood was incubated with this cell-free supernatant for $2 \mathrm{~h}$ at $37^{\circ} \mathrm{C}$, followed by centrifugation at $800 \mathrm{~g}$ for $15 \mathrm{~min}$. OD of the supernatant was read at $490 \mathrm{~nm}$, to quantify the amount of hemoglobin released. 1\% Triton X-100 (CDH, New Delhi; CDH030632) was used as a positive control. Phosphate buffer saline was used as a negative control.

d. Effect of Triphala on lysozyme-susceptibility of test pathogens: Bacterial cells were first inoculated in a TF-containing media for $24 \mathrm{~h}$, and then the cell pellet was separated by centrifugation $[15,000 \mathrm{rpm}(21130 \mathrm{~g})$ for $15 \mathrm{~min}$ ] to be resuspended into phosphate buffer saline (PBS; pH 7.4), so as to attain $\mathrm{OD}_{750}=1$ (Biorad 680). $200 \mu \mathrm{l}$ of this bacterial suspension was mixed with lysozyme (750 $\mu \mathrm{g} / \mathrm{ml}$; Sigma Aldrich L6876-1G) prepared in PBS, and then incubated for $24 \mathrm{~h}$ at appropriate temp for each organism. At the end of incubation $\mathrm{OD}_{750}$ was measured.

Effect of TF on probiotic strains

Bifidobacterium bifidum (NCDC 255), Enterococcus faecium (NCIM 5366), and Lactobacillus plantarum (MTCC 
2621) were grown in Lactobacillus MRS broth (HiMedia GM369-500G) containing TF, in screw capped tubes at $37^{\circ} \mathrm{C}$ for $22-24 \mathrm{~h}$. For B. bifidum, this medium was supplemented with $0.05 \%$ cysteine (HiMedia PCT0305-25G). Effect of TF $(10-100 \mu \mathrm{g} / \mathrm{ml})$ on these bacteria was interpreted by comparing their cell density $\left[\mathrm{OD}_{655}\right.$ measured with microplate reader (Biorad 680)] in TF-supplemented media to that in TF-free media.

\section{Statistical analysis}

All the experiments were performed in triplicate, and measurements are reported as mean \pm standard deviation (SD) of 3 independent experiments. Statistical significance of the data was evaluated by applying $t$-test using Microsoft Excel ${ }^{\circledR} 2013$. $p$ values $\leq 0.05$ were considered to be statistically significant. Trial version of GraphPad Prism 7 was used to make Kaplan-Meier survival curve for worms.

\section{Results}

In vivo experiments

Anti-infective assay. When all the five pathogens were pretreated with Triphala $(0.5-100 \mu \mathrm{g} / \mathrm{ml})$ before being allowed to attack C.elegans, Triphala formulation (TF) was able to attenuate virulence of all test pathogens except $S$. pyogenes at $\leq 20 \mu \mathrm{g} / \mathrm{ml}$ [Figure 1; underlying data (Patel et al., 2019c)]. Worms challenged with TF-treated pathogens demonstrated $18-45.50 \%$ better survival than those challenged with TF-unexposed pathogens. Effect of catechin and standard antibiotics (both used as positive controls) on bacterial virulence is shown in Figure 2 [underlying data (Patel et al., 2019c)].

After confirming the anti-infective activity of TF, we investigated (as described in Patel et al., 2019a) whether this formulation exerts any post-extract effect (PEE - https://doi.org/10.32388/359873) on the test pathogens i.e. whether the virulence-attenuating effect suffered by the parent bacterial culture is retained even in their daughter population never receiving any direct exposure to TF. When the TF-treated bacteria were subsequently subcultured on TF-free media, their daughter populations were unable to exert virulence at par with that of control (DMSOtreated parent culture). In case of $P$. aeruginosa and $S$. aureus, this PEE lasted up to the second subculturing, whereas in the case of $S$. marcescens PEE lasted until first subculturing [Figure 3; underlying data (Patel et al., 2019c)].

TF as a post-infection therapy. To test the therapeutic efficacy of TF in already-infected worm population, we first allowed different pathogenic bacteria (not previously exposed to TF) to infect $C$. elegans either for $6 \mathrm{~h}$ or $24 \mathrm{~h}$, and then exposed the infected worms to two different concentrations of TF. TF failed to exert any therapeutic effect on worms infected with $P$. aeruginosa. However, it could exert significant $(\mathrm{p} \leq 0.05)$ therapeutic effect on worms infected with $C$. violaceum or $S$. marcescens. Against $S$. aureus, TF was effective only if the worms were given TF-treatment early (i.e. 6 hour-post infection) [Figure 4; underlying data (Patel et al., 2019c)]. TF could also not rescue the worms if they already had a mixed infection (S. aureus and P. aeruginosa).
Prophylactic potential of $\boldsymbol{T F}$. To investigate whether previous feeding with TF can make the worm population tolerate subsequent challenge with pathogenic bacteria (not treated with TF) better; worms were first maintained in a TF-containing M9 buffer for $96 \mathrm{~h}$, and then challenged with different bacterial pathogens. Such TF-fed worms scored $14.50-41.50 \%$ better survival in face of pathogen challenge [Figure 5; underlying data (Patel et al., 2019c)]. However, TF did not confer any prophylactic benefit on the worm population against mix-culture challenge of $P$. aeruginosa and $S$. aureus. Since prophylactic activity of any formulation can be said to stem mainly from its effect on the host, we also compared whether TF imparts any extension of longevity on the worm. Worms fed with TF $(10-20 \mu \mathrm{g} / \mathrm{ml})$ registered marginally better survival up to 11 days (Figure 6).

Repeated exposure of test pathogens to TF. Since one of the major challenges with even the most potent antimicrobial agents/ formulations is development of resistance against them by the pathogen populations, we tested whether repeated exposure of the test pathogens to TF can induce any resistance in them. For this, we subcultured two of the gram-negative test pathogens ( $P$. aeruginosa and $S$. marcescens $)$ in TF $(50 \mu \mathrm{g} / \mathrm{ml})$-containing broth for 10 subsequent times, and then the 'TF-habituated' cultures thus obtained were tested for their virulence towards the nematode host. Repeated TF-exposure was found to induce resistance in S. marcescens [Figure 7A; underlying data (Patel et al., 2019c)]. Though TF-habituated $P$. aeruginosa could kill more worms than its counterpart receiving single TF-exposure, it still could not kill as many worms as TF-unexposed $P$. aeruginosa [Figure 7B; underlying data (Patel et al., 2019c)]. These results indicate that it may be difficult for the pathogenic bacteria to develop complete resistance against polyherbal formulations like Triphala, but not impossible. Though our previous results on other polyherbal formulations (Joshi et al., 2019; Patel et al., 2019a) and multicomponent crude plant extracts (Joshi, 2019) have indicated that the probability of pathogens developing resistance against multi-component anti-virulence preparations is low, such a probability can certainly not be ruled out (Kalia et al., 2014; Singh, 2014)

\section{In vitro experiments}

Since TF showed significant in vivo anti-pathogenic potential in the $C$. elegans model, we performed various in vitro experiments to gain insight into its interaction with the target pathogens. TF was able to modulate production of quorum sensing (QS)-regulated pigments in all the three gram-negative bacteria [Figure 8; underlying data (Patel et al., 2019c)]. It did so with $S$. marcescens without affecting its growth, which is characteristic of an ideal anti-virulence agent i.e. attenuation of virulence without exerting any selection pressure on the susceptible pathogen. However, TF did exert a growth-inhibitory effect on $P$. aeruginosa, wherein its $\mathrm{IC}_{50}$ was observed to be near $50 \mu \mathrm{g} / \mathrm{ml}$. The quorum modulatory effect of TF on pigment production in $P$. aeruginosa was observed not to be amenable to be described by a linear dose-response curve. It seems to fall within the realm of hormesis (Calabrese, 2004). For example, production of both pigments was not affected 


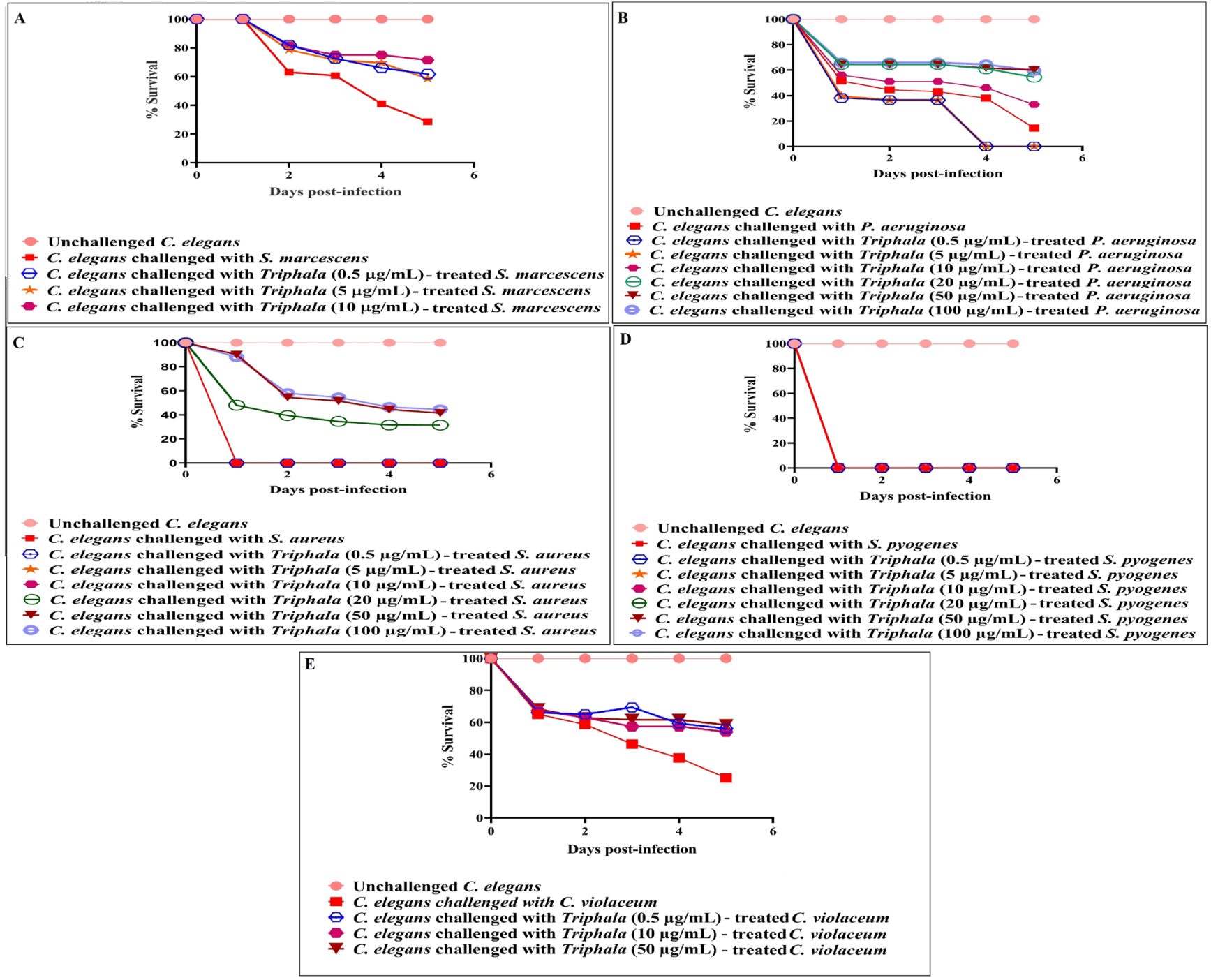

Figure 1. Anti-infective activity of Triphala formulation against test pathogens. TF-treatment attenuated virulence of four of the test pathogens towards $C$. elegans. DMSO present in the 'vehicle control' at $0.5 \% \mathrm{v} / \mathrm{v}$ did not affect virulence of any of the bacterium towards C. elegans; DMSO $(0.5 \% \mathrm{v} / \mathrm{v})$ and TF at tested concentrations showed no toxicity towards the worm. (A) TF at $0.5 \mu \mathrm{g} / \mathrm{ml}, 5 \mu \mathrm{g} / \mathrm{ml}, 10 \mu \mathrm{g} / \mathrm{ml}$, $20 \mu \mathrm{g} / \mathrm{ml}, 50 \mu \mathrm{g} / \mathrm{ml}$, and $100 \mu \mathrm{g} / \mathrm{ml}$ allowed $32 \% \pm 5.10,29 \%^{* * *} \pm 9.60,41.9 \%^{* * \star} \pm 2.40,38.4 \%^{* \star *} \pm 7.10,39.9 \%^{* * *} \pm 9.40$, and $41.4 \%^{* \star \star} \pm 7.10$ better survival of the worm population respectively, when challenged with $S$. marcescens. Also see videos a-b submitted as part of extended data. (B) TF at $10 \mu \mathrm{g} / \mathrm{ml}, 20 \mu \mathrm{g} / \mathrm{ml}, 50 \mu \mathrm{g} / \mathrm{ml}, 100 \mu \mathrm{g} / \mathrm{ml}$ allowed $18 \%^{* * *} \pm 5.01,40 \%^{* \star *} \pm 7.01,45.5 \%^{* * *} \pm 0$, and $45 \%^{* * *} \pm 5.00$ better survival of the worm population respectively, when challenged with $P$. aeruginosa. (C) TF at $20 \mu \mathrm{g} / \mathrm{ml}, 50 \mu \mathrm{g} / \mathrm{ml}$ and $100 \mu \mathrm{g} / \mathrm{ml}$ allowed $31.5 \% \pm^{* * *} 2.35$, $41.5 \%^{* * *} \pm 2.35$ and $44.5 \%^{* * \star} \pm 14.14$ better survival of the worm population respectively, when challenged with $S$. aureus. (D) TF-treatment did not attenuate virulence of $S$. pyogenes towards the worms. (E) TF at $0.5 \mu \mathrm{g} / \mathrm{ml}, 5 \mu \mathrm{g} / \mathrm{ml}, 10 \mu \mathrm{g} / \mathrm{ml}, 20 \mu \mathrm{g} / \mathrm{ml}, 50 \mu \mathrm{g} / \mathrm{ml}, 100 \mu \mathrm{g} / \mathrm{ml}$ allowed $31 \%^{* \star *} \pm 5.77,29.5 \%^{* \star *} \pm 8.81,29 \%^{* * *} \pm 1.92,29 \%^{* * \star} \pm 1.92,32.3 \%^{* * *} \pm 1.92$, and $32.3 \%^{* *} \pm 5.09$ better survival of the worm population respectively, when challenged with $C$. violaceum. ${ }^{*} \mathrm{p}<0.05,{ }^{* *} \mathrm{p}<0.01,{ }^{* *} \mathrm{p}<0.001$; TF: Triphala Formulation.

maximally at the highest test concentration. Pyocyanin production was inhibited more at $0.5 \mu \mathrm{g} / \mathrm{ml}$ than at $20 \mu \mathrm{g} / \mathrm{ml}$. Effect of $\mathrm{TF}$ on pyoverdine production followed a linear threshold model within concentration range of $0.5-50 \mu \mathrm{g} / \mathrm{ml}$, but it took an inverted-U shape over $20-100 \mu \mathrm{g} / \mathrm{ml}$. Though the exact mechanism responsible for a non-linear dose-response relationship is not known, it may be the varying magnitude of bacterial adaptive response at different concentrations of the test agent, which generates such non-linear response curves (Lushchak, 2014).

We also tested the effect of TF on two important virulence traits of the bacterial pathogens i.e. haemolytic activity, and biofilm. Though TF could not curb haemolytic activity of any of the gram-negative bacteria, this activity of $S$. aureus was heavily inhibited under the influence of TF [Figure 9; underlying data 

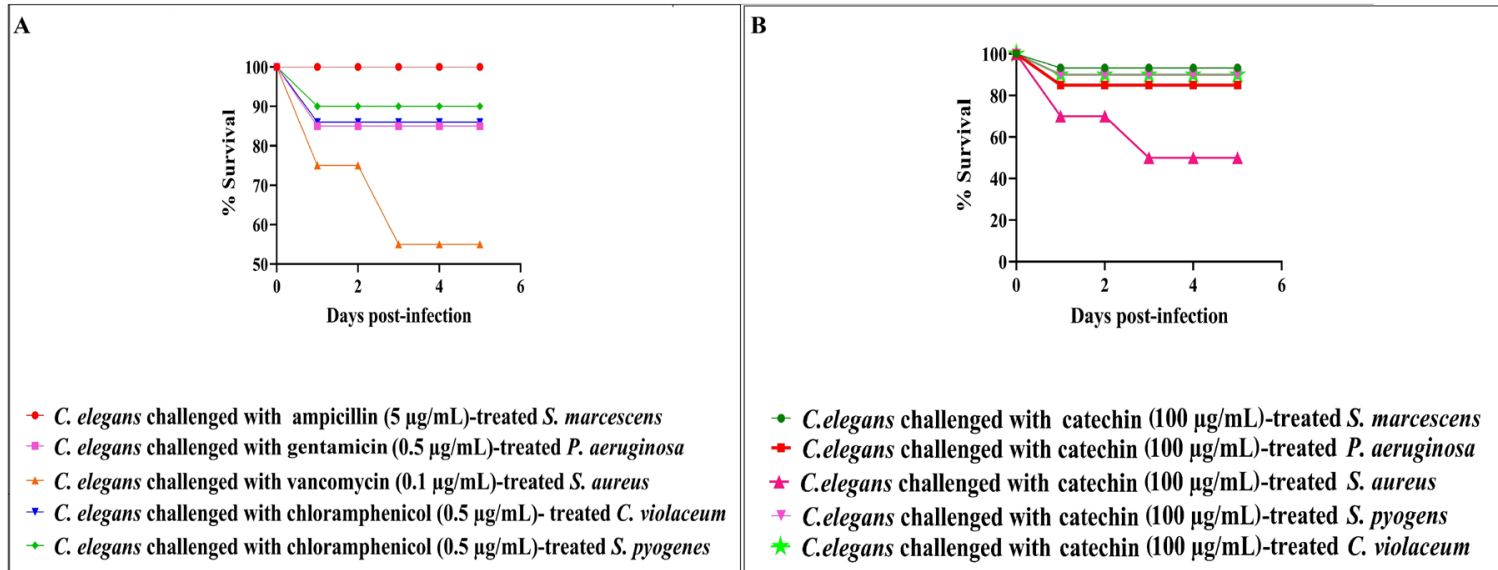

Figure 2. Anti-infective activity of positive controls (catechin and antibiotics) against test pathogens. Catechin was able to reduce virulence of different test bacteria towards C. elegans by $50-100 \%(p \leq 0.05)$. Various standard antibiotics at sub-MIC level could reduce bacterial virulence by $55-100 \%(p \leq 0.05)$.

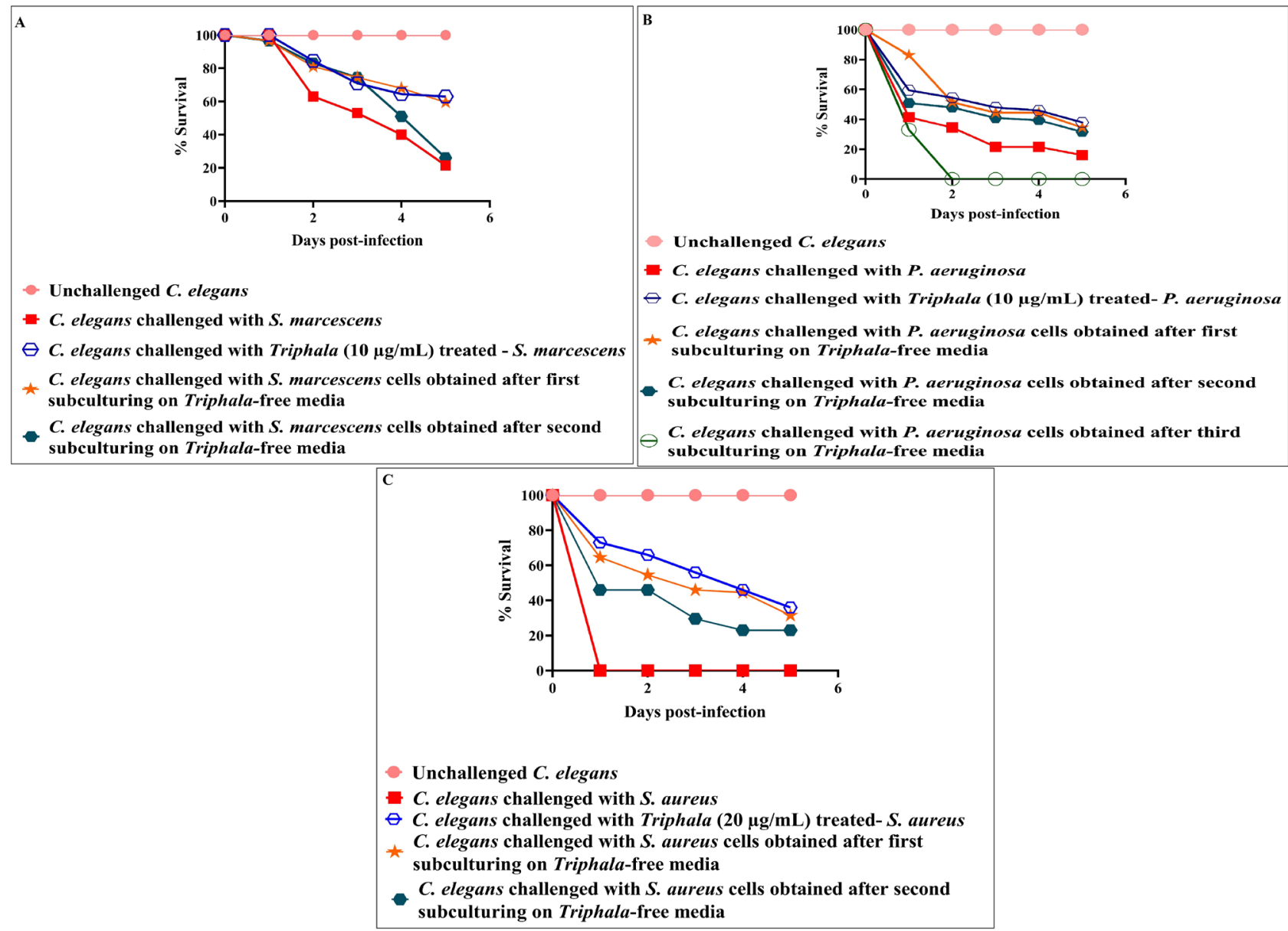

Figure 3. Post extract effect of Triphala on test pathogens. TF-treatment reduces the virulence of all the test pathogens towards $C$. elegans even after subculturing of cells in TF-free media. DMSO present in the 'vehicle control' at $0.5 \% \mathrm{v} / \mathrm{v}$ did not affect virulence of the bacterium towards C. elegans; DMSO $(0.5 \% \mathrm{v} / \mathrm{v})$ and TF at tested concentrations showed no toxicity towards the worm. (A) S. marcescens obtained after first subculturing on TF-free media were able to kill $38 \%{ }^{* * *} \pm 4.71$ lesser worms than control; (B) P. aeruginosa and obtained after first and second subculturing on TF-free media were able to kill $18.5 \%{ }^{* *} \pm 2.35$ and $15.5 \%^{*} \pm 2.35$ lesser worms respectively, than control; (C) S. aureus obtained after first and second subculturing on TF-free media were able to kill $31.5 \%^{* *} \pm 2.35$ and $23 \%^{* * *} \pm 0$ lesser worms respectively, than control. ${ }^{*} p<0.05,{ }^{* *} p<0.01,{ }^{* *} p<0.001 ;$ TF: Triphala Formulation. 


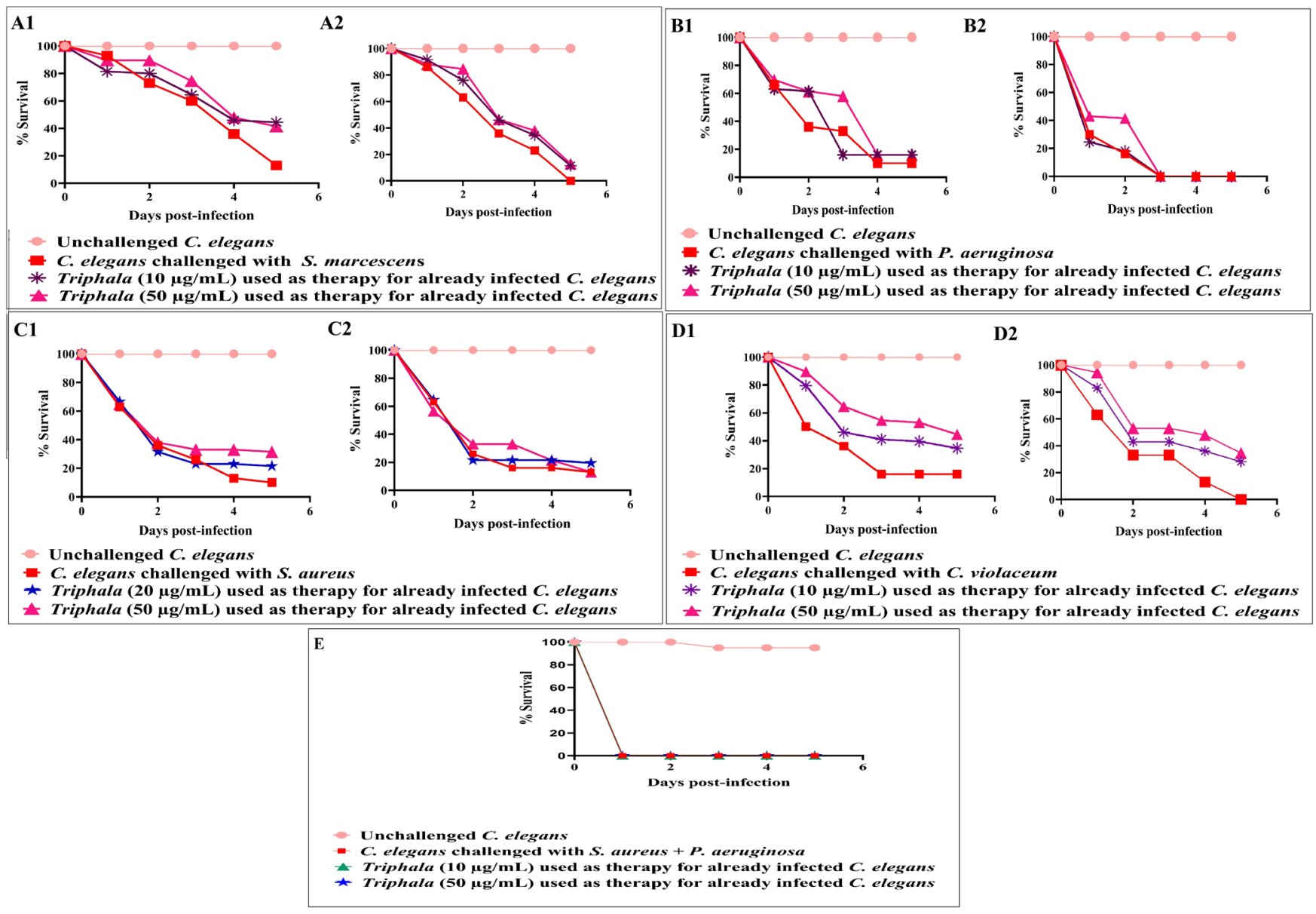

Figure 4. Assessing efficacy of Triphala as a post-infection therapy in pre-infected worms. DMSO $(0.5 \% \mathrm{v} / \mathrm{V})$ did not affect survival of pre-infected worms. DMSO $(0.5 \% \mathrm{v} / \mathrm{v})$ and TF at tested concentrations showed no toxicity towards the worm. A1-D1: TF employed $6 \mathrm{~h}$ post-infection A2-D2: TF employed 24 h post-infection (A1) TF at $10 \mu \mathrm{g} / \mathrm{ml}, 50 \mu \mathrm{g} / \mathrm{ml}$ used as therapy for already S. marcescens infected C. elegans after $6 \mathrm{~h}$ incubation conferred $31.5 \%^{* * *} \pm 2.35$ and $28.5 \%^{* *} \pm 2.35$ survival benefit, respectively; $($ A2 $)$ TF at $10 \mu \mathrm{g} / \mathrm{ml}, 50 \mu \mathrm{g} / \mathrm{ml}$ used as therapy for already S. marcescens infected $C$. elegans after $24 \mathrm{~h}$ incubation conferred $11.5 \%^{* * *} \pm 2.35$ and $13 \%^{* * *}$ survival benefit, respectively; (B1-B2):TF could not rescue P. aeruginosa-infected worms when tested as post-infection remedy. (C1) TF at $20 \mu \mathrm{g} / \mathrm{ml}, 50 \mu \mathrm{g} / \mathrm{ml}$ used as therapy for already S. aureus infected $C$. elegans after $6 \mathrm{~h}$ incubation conferred $11.5 \%^{\star * \star} \pm 2.35$ and $21.5 \%^{* * *} \pm 2.35$ survival benefit, respectively; (C2) TF could not rescue S. aureus infected worms when tested as post-infection remedy. (D1) TF at $10 \mu \mathrm{g} / \mathrm{ml}, 50 \mu \mathrm{g} / \mathrm{ml}$ used as therapy for already $C$. violaceum infected $C$. elegans after $6 \mathrm{~h}$ incubation conferred $18.5 \%^{* \star \star} \pm 2.35$ and $28.5 \%^{* \star *} \pm 2.35$ survival benefit, respectively; (D2) TF at $10 \mu \mathrm{g} / \mathrm{ml}, 50 \mu \mathrm{g} / \mathrm{ml}$ used as therapy for already $C$. violaceum infected $C$. elegans after $24 \mathrm{~h}$ incubation conferred $22 \%^{* * *} \pm 2.35$ and $28.5 \%^{* * *} \pm 2.35$ survival benefit, respectively. (E) TF could not rescue the worms in face of mix-culture infection by $S$. aureus and $P$. aeruginosa, when tested as post-infection remedy. Survival benefit refers to the difference between number of worms surviving in experimental and control wells. ${ }^{\star} p<0.05,{ }^{\star \star} p<0.01,{ }^{\star \star *} p<0.001$; TF: Triphala Formulation.

(Patel et al., 2019c)]. While P. aeruginosa biofilm was not affected by TF, TF was able to reduce biofilm formation by $S$. marcescens, and $S$. aureus. When TF was applied on pre-formed bacterial biofilms, it seemed to enhance synthesis of the biofilm matrix material (quantified thorough crystal violet assay), and also the metabolic activity (measured in terms of organism's ability to reduce MTT) of the bacterial biofilm [Figure 10; underlying data (Patel et al., 2019c)]. It may be speculated that TF-treatment induces stress in the bacterial population residing in biofilm form, and this causes the bacteria to mount stress-response. Slow metabolism is a general characteristic of bacterial biofilms (Singh et al., 2017), but $\mathrm{TF}$ seems to have forced the biofilms of two of our test bacteria to enhance the rate of their metabolic activity, as well as synthesis/secretion of biofilm matrix components (e.g. polysaccharides, proteins, and extracellular DNA). Enhanced production of exopolysaccharide and e-DNA is believed to occur in stressed bacterial populations (Chang et al., 2007; Zatorska et al., 2018). Sub-inhibitory concentrations of betalactam antibiotics have been reported to induce extracellular 

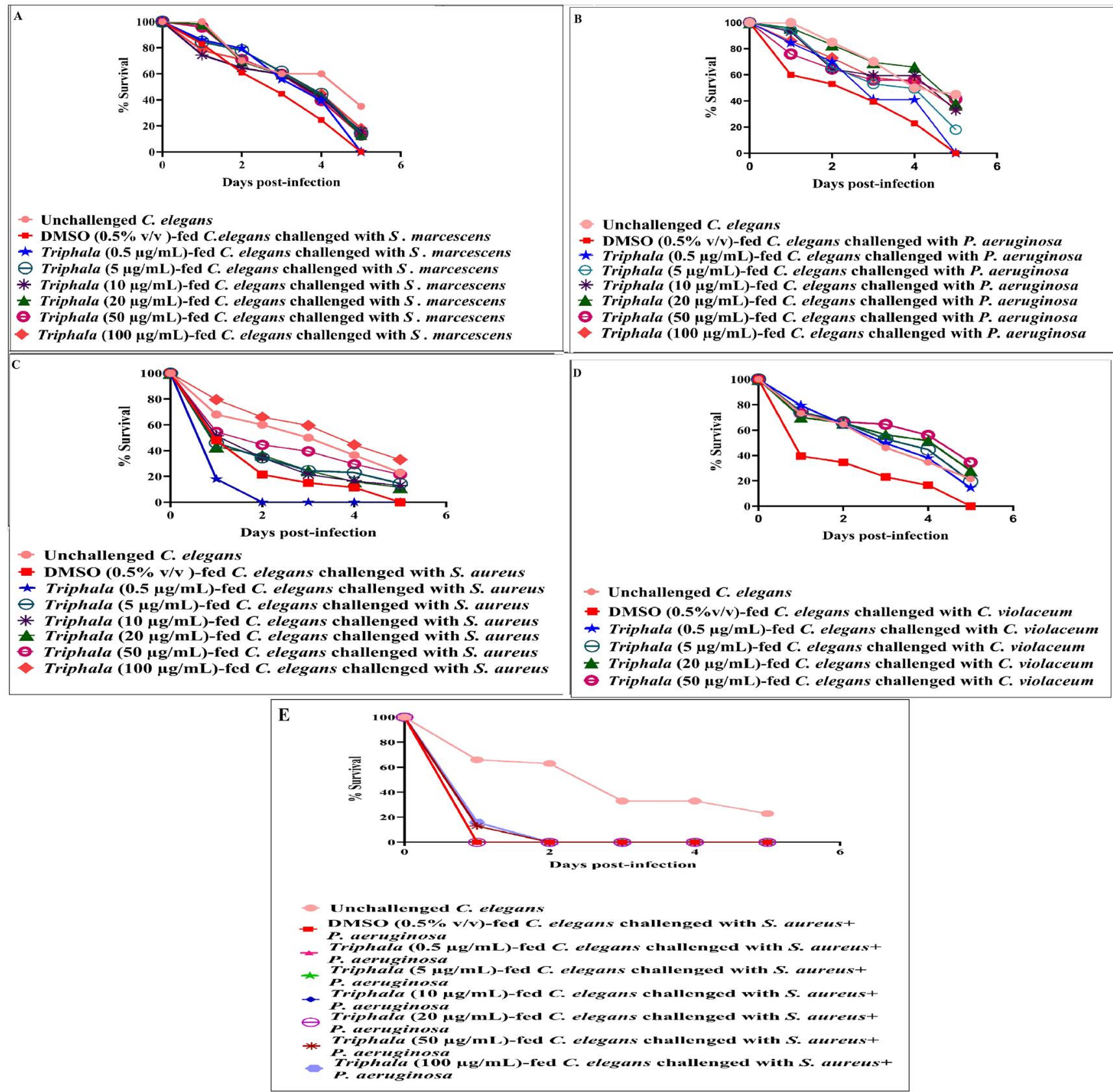

Figure 5. TF-pre-exposed C. elegans exhibit better resistance to subsequent bacterial challenge. Pre-treatment of worms with DMSO $(0.5 \% \mathrm{v} / \mathrm{v})$ did not alter their susceptibility to subsequent challenge with pathogenic bacteria. DMSO $(0.5 \% \mathrm{v} / \mathrm{v})$ and TF at tested concentrations showed no toxicity towards the worm. Among positive controls, catechin $(100 \mu \mathrm{g} / \mathrm{ml})$ pre-treatment conferred $23 \% \pm 0$ protection on worm population against subsequent S. marcescens, $P$. aeruginosa, S. aureus, and $C$. violaceum challenge; (A) Ampicillin $(5 \mu \mathrm{g} / \mathrm{ml})$ pre-treatment conferred $26 \% \pm 0$ protection on worm populations against subsequent $S$. marcescens challenge; TF $(100 \mu \mathrm{g} / \mathrm{ml})$ pre-treatment conferred $18 \%^{* * *} \pm 2.35$ protection on fifth day worm population against subsequent $S$. marcescens challenge; (B) Gentamicin $(0.5 \mu \mathrm{g} / \mathrm{ml})$ pre-treatment conferred $26 \%$ protection on worm populations against subsequent $P$. aeruginosa challenge; TF pretreatment at $5 \mu \mathrm{g} / \mathrm{ml}, 10 \mu \mathrm{g} / \mathrm{ml}, 20 \mu \mathrm{g} / \mathrm{ml}$, $50 \mathrm{\mu g} / \mathrm{ml}, 100 \mathrm{\mu g} / \mathrm{ml}$, conferred $18 \%^{* * *} \pm 0,33 \%^{* * *} \pm 2.35,38 \%^{* * *} \pm 2.35,41.5 \%^{\star *} \pm 0$ and $34.5 \%^{* * *} \pm 2.35$ protection on worm population against subsequent $P$. aeruginosa challenge $(\mathbf{C})$ Vancomycin $(0.1 \mu \mathrm{g} / \mathrm{ml})$ pre-treatment conferred $26 \%$ protection on worm population, TF pretreatment at $5 \mu \mathrm{g} / \mathrm{ml}, 10 \mu \mathrm{g} / \mathrm{ml}, 20 \mu \mathrm{g} / \mathrm{ml}, 50 \mu \mathrm{g} / \mathrm{ml}, 100 \mu \mathrm{g} / \mathrm{ml}$, conferred $14.5 \%^{* * \star} \pm 2.35,13 \%^{* * *} \pm 4.71,11.5 \%^{* * *} \pm 2.35,21.5 \%^{* * *} \pm 2.35$, and $33 \%^{* * *} \pm 0$ protection on worm population against $S$. aureus (D) Chloramphenicol $(0.5 \mu \mathrm{g} / \mathrm{ml})$ pre-treatment conferred $26 \%$ protection on worm population against $C$. violaceum, TF pre-treatment at $0.5 \mu \mathrm{g} / \mathrm{ml}, 5 \mu \mathrm{g} / \mathrm{ml}, 10 \mu \mathrm{g} / \mathrm{ml}, 20 \mu \mathrm{g} / \mathrm{ml}, 50 \mu \mathrm{g} / \mathrm{ml}, 100 \mu \mathrm{g} / \mathrm{ml}$, conferred $14.5 \%{ }^{* * *} \pm 0$, $19.5 \%^{* * *} \pm 4.71,14.5 \%^{* * *} \pm 2.35,28 \%^{* * *} \pm 7.07,34.5 \%^{* * *} \pm 2.35$ and $35.5 \%^{* * *} \pm 0$ protection on worm population against $C$. violaceum. ${ }^{*} p<0.05$, ${ }^{* *} \mathrm{p}<0.01,{ }^{* * *} \mathrm{p}<0.001 ; \mathrm{TF}$ : Triphala Formulation. 


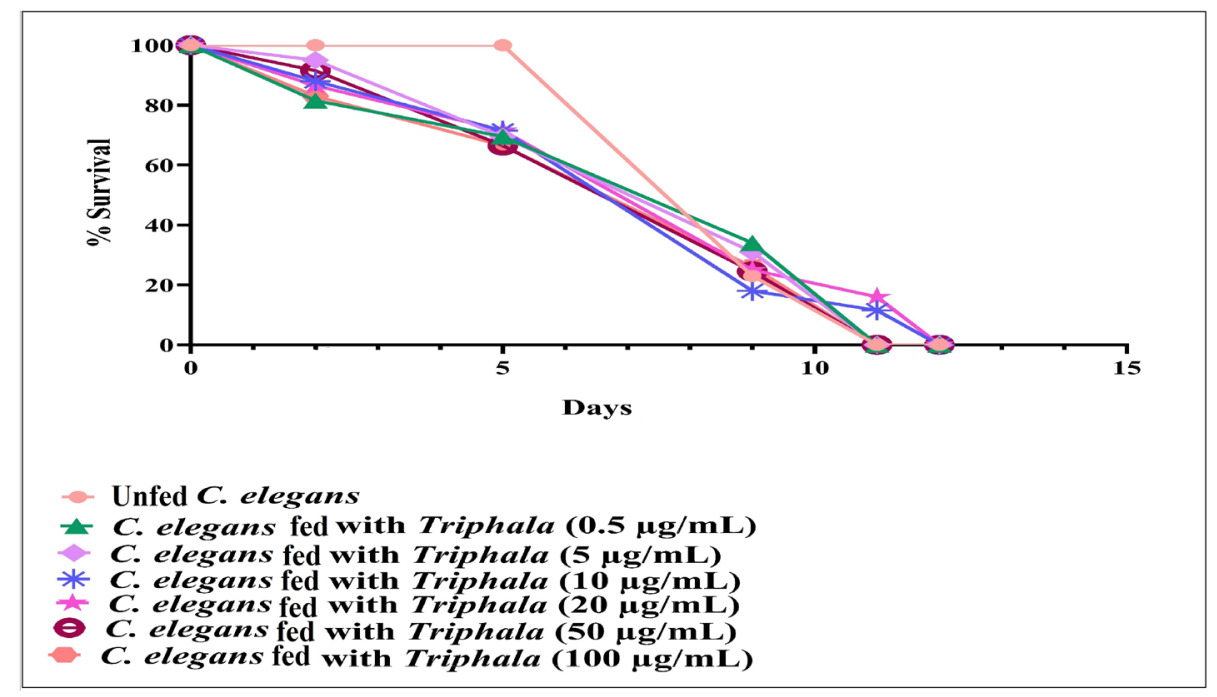

Figure 6. Triphala imparts marginal longevity extension on C. elegans. Worms fed with TF $(10 \mu \mathrm{g} / \mathrm{ml} \mathrm{and} 20 \mu \mathrm{g} / \mathrm{ml}) \mathrm{scored} 11.5 \%$ *** \pm 1.20 , and $16 \%^{* *} \pm 0.96$ better survival on $11^{\text {th }}$ day. All worms (not fed with TF) in control were dead by the $11^{\text {th }}$ day. DMSO $(0.5 \% \mathrm{v} / \mathrm{V})$ and TF at tested concentration had no effect on worm longevity. ${ }^{* *} \mathrm{p} \leq 0.001$; TF: Triphala Formulation.
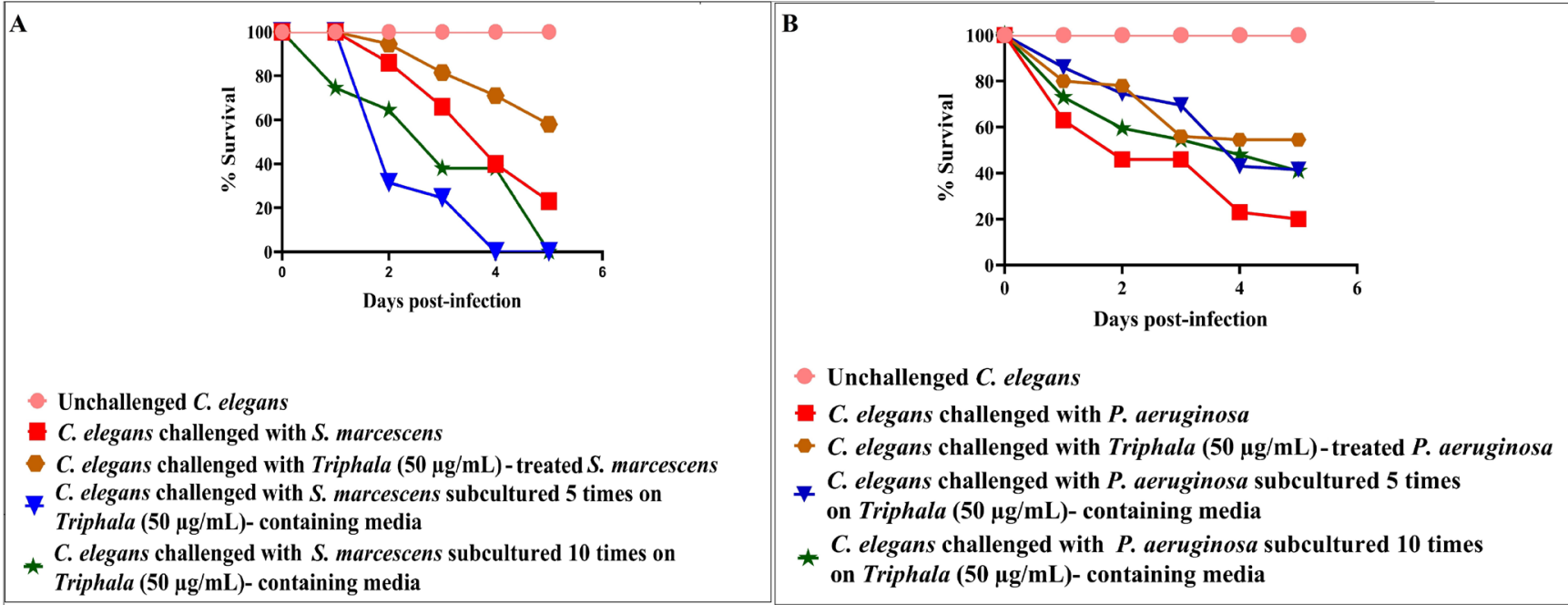

Figure 7. Effect of repeated exposure of Triphala on test pathogens. DMSO present in the 'vehicle control' at $0.5 \% \mathrm{v} / \mathrm{v}$ did not affect virulence of the bacterium towards $C$. elegans; DMSO $(0.5 \% \mathrm{v} / \mathrm{v})$ and TF at tested concentrations showed no toxicity towards the worm. (A) C. elegans challenged with TF $(50 \mu \mathrm{g} / \mathrm{ml})$ treated S. marcescens conferred $35 \%{ }^{\star * *} \pm 2.35$ survival benefit. C. elegans could not conferred survival benefit when challenged with S. marcescens which subcultured 5 times or 10 times on TF containing media could not conferred survival benefit. (B) P. aeruginosa obtained after 5 and 10 subculturings in TF (50 $\mu \mathrm{g} / \mathrm{ml})$-containing media were able to kill $21.5 \%^{* * *} \pm 2.35$ and $21 \%^{* \star *} \pm 7.07$ lesser worms respectively, as compared to control (DMSO-treated) bacterial population. ${ }^{*} \mathrm{p}<0.05,{ }^{* *} \mathrm{p}<0.01,{ }^{* * *} \mathrm{p}<0.001$; TF: Triphala Formulation.

DNA release and biofilm formation in some $S$. aureus strains (Kaplan et al., 2012).

During the host-pathogen interaction, host defense mechanisms play a determinant role in deciding the outcome of this interaction.
Since lysozyme is an important component of the innate defense machinery of human immune system against invading microbes (Herbert et al., 2007), we also studied whether TF can have any effect on susceptibility of the test pathogens to lysozyme. TF-treated cells of $S$. marcescens and $S$. aureus 

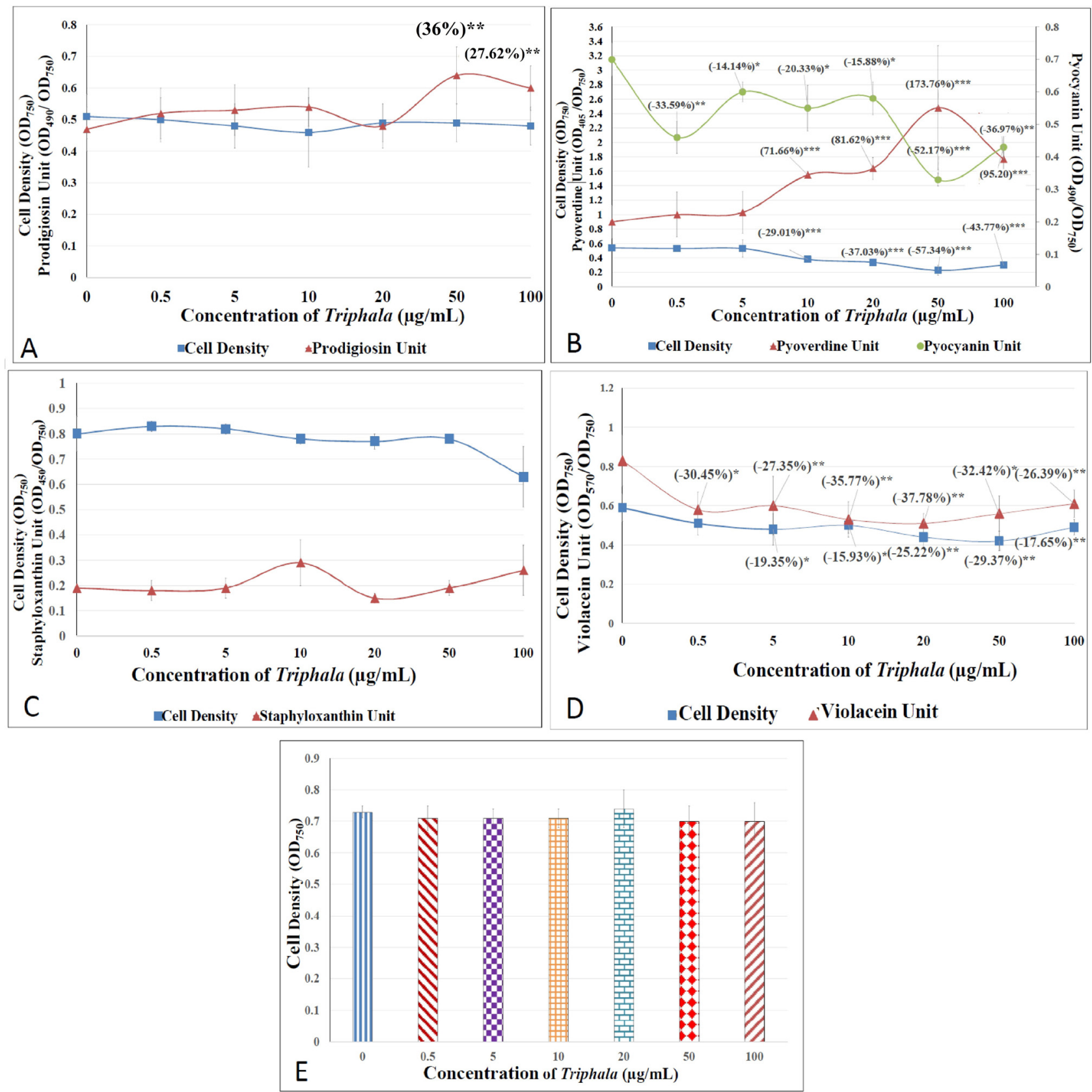

Figure 8. Effect of Triphala on growth and QS-regulated pigment production in test pathogens. Bacterial cell density was quantified as $\mathrm{OD}_{750} \mathrm{DMSO}(0.5 \% \mathrm{v} / \mathrm{v})$ in the vehicle control did not affect growth and pigment production in any of the test pathogens. (A) S. marcescens: OD of prodigiosin was measured at $490 \mathrm{~nm}$, and Prodigiosin Unit was calculated as the ratio $\mathrm{OD}_{490} / \mathrm{OD}_{750}$ (an indication of prodigiosin production per unit of growth). Catechin $(100 \mu \mathrm{g} / \mathrm{ml})$ inhibited prodigiosin production by $13.05 \%{ }^{*} \pm 0.10$ without affecting bacterial growth; Ampicillin $(5 \mu \mathrm{g} / \mathrm{ml})$ inhibited growth and prodigiosin production by $8.48 \%^{* *} \pm 0.02$ and $40.60 \%{ }^{*} \pm 0.23$, respectively. (B) P. aeruginosa: OD of pyoverdine and pyocyanin was measured at $405 \mathrm{~nm}$ and at $490 \mathrm{~nm}$. Pyoverdine Unit and Pyocyanin Unit was calculated as the ratio $\mathrm{OD}_{405} / \mathrm{OD}_{750}$ and $\mathrm{OD}_{490} / \mathrm{OD}_{750}$ (an indication of pyoverdine and pyocyanin production per unit of growth). Catechin (100 $\left.\mu \mathrm{g} / \mathrm{ml}\right)$ inhibited, pyoverdine and pyocyanin production by $3.85 \%{ }^{*} \pm 0.38$ and $12.74 \%{ }^{*} \pm 2.60$ without affecting bacterial growth; Gentamicin $(0.5 \mu \mathrm{g} / \mathrm{ml})$ inhibited, pyoverdine, pyocyanin production by $10.53 \%^{\star} \pm 2.07$ and $57.93 \%{ }^{* \star \star} \pm 6.47$ without affecting bacterial growth; (C) S. aureus: OD of staphyloxanthin was measured at $450 \mathrm{~nm}$, and Staphyloxanthin Unit was calculated as the ratio $\mathrm{OD}_{450} / \mathrm{OD}_{750}$ (an indication of staphyloxanthin production per unit of growth). Catechin $(100 \mu \mathrm{g} / \mathrm{ml})$ and vancomycin $(0.1 \mu \mathrm{g} / \mathrm{ml})$ did not affect growth as well as staphyloxanthin pigment production. (D) C. violaceum: OD of violacein was measured at $570 \mathrm{~nm}$, and Violacein Unit was calculated as the ratio $\mathrm{OD}_{570} / \mathrm{OD}_{750}$ (an indication of violacein production per unit of growth). Catechin $(100 \mu \mathrm{g} / \mathrm{ml})$ not affect growth as well as violacein pigment productions; Chloramphenicol

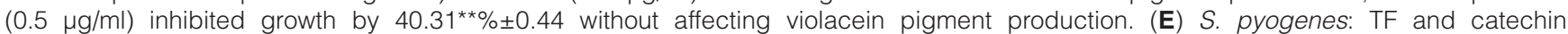
$(100 \mu \mathrm{g} / \mathrm{ml})$ did not affect the growth when measured as $\mathrm{OD}_{655}$; Chloramphenicol $(0.5 \mu \mathrm{g} / \mathrm{ml})$ inhibited growth by $7.56 \%{ }^{* *} \pm 3.46$. ${ }^{*} p<0.05$, ${ }^{* *} p<0.01,{ }^{* *} \mathrm{p}<0.001 ;$ TF: Triphala Formulation; QS: Quorum Sensing. 


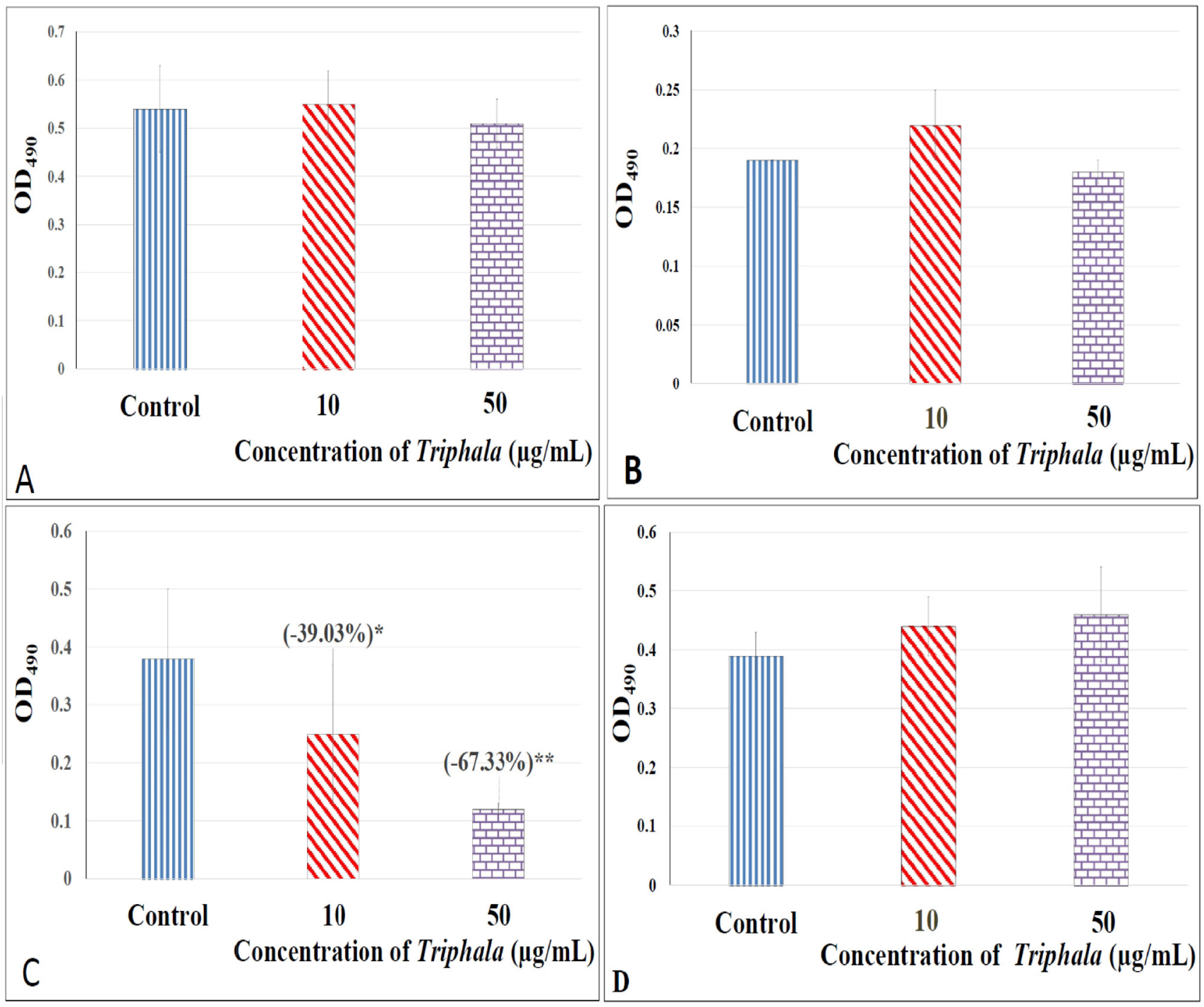

Figure 9. Effect of Triphala on haemolytic activity of test pathogens. TF had no effect on hemolytic activity of $S$. marcescens (A), P. aeruginosa (B), and C. violaceum (D). However, it curbed haemolytic potential of S. aureus notably. Hemoglobin released as a result of haemolysis was quantified as $\mathrm{OD}_{490} ; 1 \%$ triton $\left(\mathrm{OD}_{490}=1.2\right)$, and PBS $(\mathrm{pH} 7.4)$ were used as positive and negative control respectively; ${ }^{*} \mathrm{p}<0.05,{ }^{* * *} \mathrm{p}<0.001$; TF: Triphala Formulation; PBS: Phosphate Buffer Saline.

were found to suffer marginal (albeit statistically significant; $\mathrm{p} \leq 0.05)$ increase in their susceptibility to lysis by lysozyme. $P$. aeruginosa's lysozyme-susceptibility was found to increase heavily (by $\sim 25-43 \%$ ) upon TF-pretreatment [Figure 11; underlying data (Patel et al., 2019c)].

Most conventional antibiotics suffer from an inherent limitation of not being selectively inhibitory to pathogenic bacteria, and they simultaneously inhibit resident bacterial members of the human microbiome; which may lead to gut dysbiosis (Wipperman et al., 2017). Thus an ideal anti-pathogenic formulation should exert anti-pathogenic effects without inhibiting indigenous members of human microbiome. We tested TF's effect on three such bacteria (Enterococcus faecium, Bifidobacterium bifidum, and Lactobacillus plantarum) which are part of human microbiome, and also used as probiotic strains. Though TF did not exert any prebiotic potential by promoting growth of the probiotic bacteria, it also had no negative effect on them [Extended data: Figure S1 (Patel et al., 2019c)].

\section{Conclusion}

This study has found the classical Triphala formulation to possess significant anti-infective potential against various gram-positive and gram-negative pathogenic bacteria. It was 

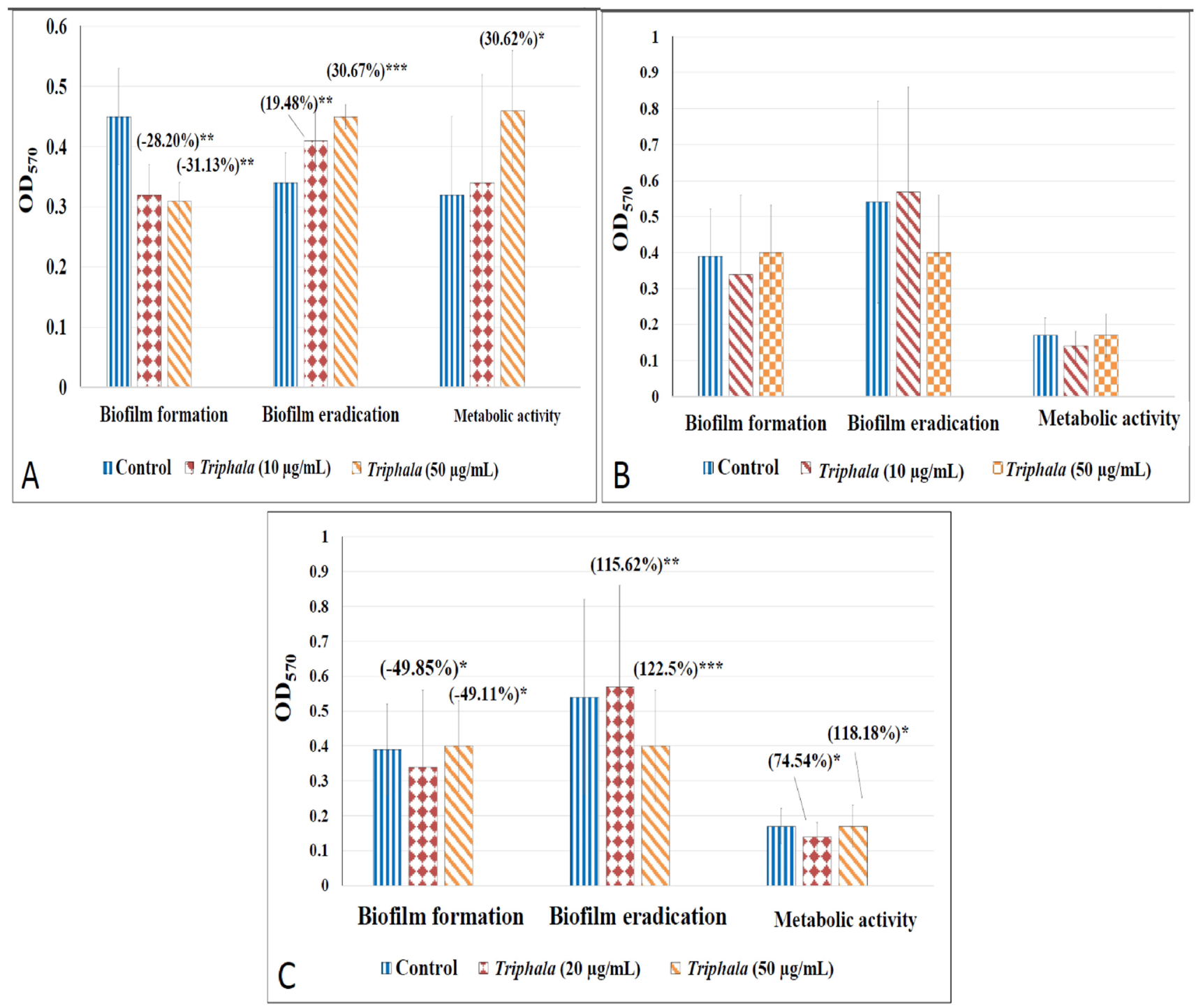

Figure 10. Effect of Triphala on biofilm of test pathogens. Crystal violet assay was performed to quantify biofilm formation or eradication, wherein amount of this dye retained by the biofilm was read at $570 \mathrm{~nm}$ after extracting it in ethanol. MTT assay was performed to quantify biofilm viability (metabolic activity), wherein change in colour of the MTT dye owing to bacterial metabolism was read at $570 \mathrm{~nm}$. Catechin $(100 \mu \mathrm{g} / \mathrm{ml})$ for all test bacteria, ampicillin $(5 \mu \mathrm{g} / \mathrm{ml})$ for $S$. marcescens, gentamicin $(0.5 \mu \mathrm{g} / \mathrm{ml})$ for $P$. aeruginosa, and vancomycin $(0.1 \mu \mathrm{g} / \mathrm{ml})$ for S. aureus were used as positive controls. (A) Effect of TF on S. marcescens biofilm. Catechin inhibited S. marcescens biofilm formation by $(29.80 \pm 9.38) \%^{* * *}$, eradicated pre-formed biofilm by $(49.60 \pm 12.00) \% *$, and reduced metabolic activity of biofilm by $(86.20 \pm 0.88) \%{ }^{* \star *}$. Ampicillin inhibited all three by $29.25^{\star \star *} \pm 7.30,54.23^{\star \star \star} \pm 3.67,86.11^{\star \star \star} \pm 0.21$ for S. marcescens. (B) Effect of TF on $P$. aeruginosa biofilm. Catechin inhibited P. aeruginosa biofilm formation by $(22.18 \pm 1.16) \%$ \% $\pm 3.50) \%^{* *}$, and enhanced metabolic activity of biofilm by $(32.27 \pm 4.74) \%^{\star * *}$. Gentamicin did not affect biofilm formation, eradicated preformed biofilm by $(23.27 \pm 4.91) \%$ ***, reduced metabolic activity of biofilm by $(123.99 \pm 26.81) \%$ ***. (C) Effect of TF on S. aureus biofilm. Catechin inhibited S. aureus biofilm formation by $(26.24 \pm 7.35) \%^{\star * *}$, enhanced pre-formed biofilm by $(22.54 \pm 10.90) \%^{* *}$, and enhanced metabolic activity of biofilm by $(177.71 \pm 16.49) \%{ }^{* * *}$. Vancomycin inhibited biofilm formation by $(41.53 \pm 5.49) \%{ }^{* * *}$, eradicate pre-formed biofilm by $(42.37 \pm 11.21) \%{ }^{\star \star *}$, enhanced metabolic activity of biofilm by $(70.90 \pm 5.10) \%{ }^{* * *} .{ }^{*} p<0.05,{ }^{* *} p<0.01,{ }^{* \star} p<0.001$; TF: Triphala Formulation.

also found to be efficacious as a post-infection therapy as well as a prophylactic measure against bacterial infection. Triphala can be said to possess a broad-spectrum of anti-pathogenic activity, which seems to partly arise from its ability to interfere with bacterial quorum-sensing. Its prophylactic efficacy indicates that it is not only exerting inhibitory effect on the susceptible bacteria, but also beneficial effect on the host worm, and thus can be described as a combination of immunomodulatory and 

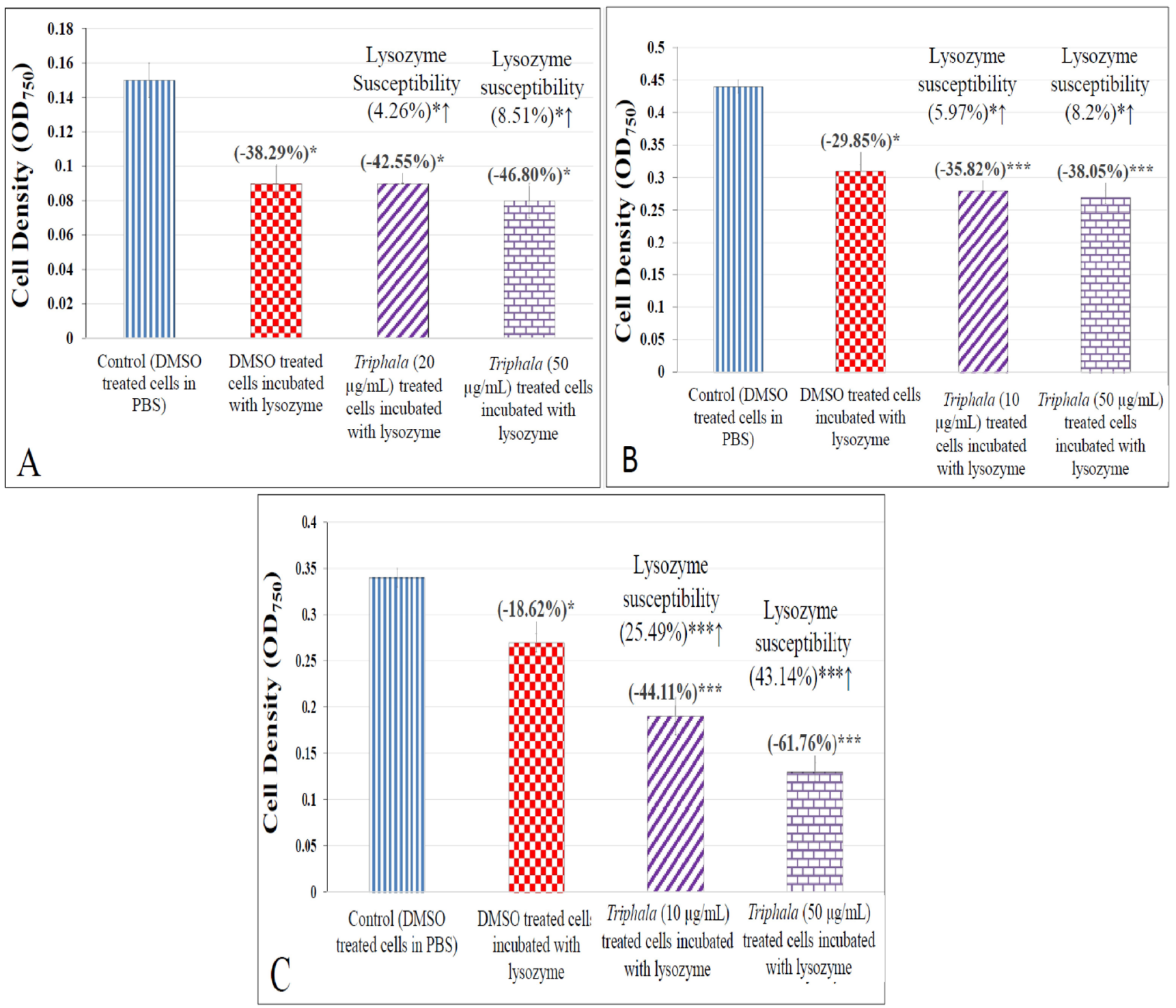

Figure 11. Triphala increases susceptibility of test pathogens to lysozyme. (A) S. aureus; (B) S. marcescens; (C) P. aeruginosa * $\leq \leq 0.05$ ${ }^{* \star *} \mathrm{p} \leq 0.001$.

anti-pathogenic activities in one formulation. Exerting such combined efficacy without displaying any negative effect on beneficial members of human microbiome are key attributes for $21^{\text {st }}$ century antimicrobials (Laxminarayan et al., 2013). Further investigation for elucidating the molecular mechanisms associated with the biological effects of Triphala are warranted, with special emphasis on its role in combating AMR. Such traditional medicine polyherbal formulations need not necessarily be thought of as replacement of conventional antibiotic treatments, but more realistically as adjunctive therapies boosting our efforts to tackle AMR effectively.

\section{Data availability}

Underlying data

Figshare: Anti-pathogenic potential of a classical ayurvedic formulation- Triphala. https://doi.org/10.6084/m9.figshare.8052143.v2 (Patel et al., 2019c)

\section{- Raw data_Figures 1-11_S1.rar}

\section{Extended data}

Figshare: Anti-pathogenic potential of a classical ayurvedic formulation- Triphala. https://doi.org/10.6084/m9.figshare.8052143.v2 (Patel et al., 2019c) 
This project contains the following extended data:

- Video (a).avi (Video of C. elegans challenged with S. marcescens)

- Video (b).avi (Video of C. elegans exposed to TF-treated S. marcescens)

- Figure S1.jpg (effect of TF treatment on probiotic bacterial strains)

Data are available under the terms of the Creative Commons Zero "No rights reserved" data waiver (CCO 1.0 Public domain dedication).
Grant information

This work was supported by Nirma Education \& Research Foundation (NERF).

The funders had no role in study design, data collection and analysis, decision to publish, or preparation of the manuscript.

\section{Acknowledgement}

Authors thank Nirma Education \& Research Foundation (NERF), Ahmedabad for financial and infrastructural support; and Virupakshi Soppina (IIT-Gn) for imaging of C. elegans.
Bag A, Bhattacharyya SK, Pal NK, et al:: Antibacterial potential of hydroalcoholic extracts of triphala components against multidrug-resistant uropathogenic bacteria--a preliminary report. Indian J Exp Biol. 2013; 51(9): 709-714. PubMed Abstract

Bhattacharjee R, Nekkanti S, Kumar NG, et al:: Efficacy of triphala mouth rinse (aqueous extracts) on dental plaque and gingivitis in children. J Investig Clin Dent. 2015; 6(3): 206-210.

PubMed Abstract | Publisher Full Tex

Calabrese EJ: Hormesis: from marginalization to mainstream: a case for hormesis as the default dose-response model in risk assessment. Toxicol Appl Pharmacol. 2004; 197(2): 125-136.

PubMed Abstract | Publisher Full Text

Chang WS, van de Mortel M, Nielsen L, et al.: Alginate production by Pseudomonas putida creates a hydrated microenvironment and contributes to biofilm architecture and stress tolerance under water-limiting conditions. J Bacteriol. 2007; 189(22): 8290-8299.

PubMed Abstract | Publisher Full Text | Free Full Text

Herbert S, Bera A, Nerz C, et al:: Molecular basis of resistance to muramidase and cationic antimicrobial peptide activity of lysozyme in staphylococci. PLOS Pathog. 2007; 3(7): e102.

PubMed Abstract | Publisher Full Text | Free Full Text

Joshi C: Investigation on anti-pathogenic potential of Panchvalkal and Punica grantum peel extract against certain human-pathogenic bacteria. Doctoral thesis. Nirma University, Ahmedabad, India. 2019.

Reference Source

Joshi C, Kothari V, Patel P: Importance of Selecting Appropriate Wavelength, While Quantifying Growth and Production of Quorum Sensing Regulated Pigments in Bacteria. Recent Pat Biotechnol. 2016; 10(2): 145-152..

PubMed Abstract | Publisher Full Text

Joshi C, Patel P, Palep H, et al.: Validation of the anti-infective potential of a polyherbal 'Panchvalkal' preparation, and elucidation of the molecular basis underlining its efficacy against Pseudomonas aeruginosa. BMC Complement Altern Med. 2019; 19(1): 19

PubMed Abstract | Publisher Full Text | Free Full Text

Kalia VC, Wood TK, Kumar P: Evolution of resistance to quorum-sensing inhibitors. Microb Ecol. 2014; 68(1): 13-23.

PubMed Abstract | Publisher Full Text | Free Full Text

Kaplan JB, Izano EA, PrernaGopal MT, et al:: Low levels of $\beta$-lactam antibiotics induce extracellular DNA release and biofilm formation in Staphylococcus aureus. mBio. 2012; 3(4): e00198-12.

PubMed Abstract | Publisher Full Text | Free Full Text

Kothari V: Validation of Traditional Medicinal Practices through Modern

Scientific Tools and Techniques. Curr Pharmacogenomics Person Med. 2018;

16(1): 3-3.

Publisher Full Text

Laxminarayan R, Duse A, Wattal C, et al: Antibiotic resistance-the need for

global solutions. Lancet Infect Dis. 2013; 13(12): 1057-1098.

PubMed Abstract | Publisher Full Text

Lushchak VI: Dissection of the hormetic curve: analysis of components and mechanisms. Dose-Response. 2014; 12(3): 466-79.

PubMed Abstract | Publisher Full Text | Free Full Text

Neun BW, llinskaya AN, Dobrovolskaia MA: Analysis of hemolytic properties of nanoparticles. NCL method ITA-1 Version, 1. 2015.

Reference Source

Patel P, Joshi C, Funde S, et al.: Prophylactic potential of a Panchgavya formulation against certain pathogenic bacteria [version 1; peer review: 3 approved]. F1000Res. 2018b; 7: 1612.

PubMed Abstract | Publisher Full Text | Free Full Text

Patel P, Joshi C, Kothari V: Antipathogenic Potential of a Polyherbal WoundCare Formulation (Herboheal) against Certain Wound-Infective Gram-Negative Bacteria. Adv Pharmacol Sci. 2019a; 2019: 1739868.

PubMed Abstract | Publisher Full Text | Free Full Text

Patel P, Joshi C, Kothari V: Anti-Pathogenic Efficacy and Molecular Targets of a Polyherbal Wound- Care Formulation (Herboheal) Against Staphylococcus aureus. Infect Disord Drug Targets. 2019b; 19(2): 193-206.

PubMed Abstract | Publisher Full Text

Patel $\mathrm{P}$, Joshi $\mathrm{C}$, Palep $\mathrm{H}$, et al.: Anti-infective potential of a quorum modulatory polyherbal extract (Panchvalkal) against certain pathogenic bacteria. J Ayurveda Integr Med. 2018a.

Publisher Full Text

Patel H, Patel F, Jani V, et al:: Anti-pathogenic potential of a classical ayurvedic formulation- Triphala. figshare. Dataset. 2019c.

http://www.doi.org/10.6084/m9.figshare.8052143.v2

Patel I, Patel V, Thakkar A, et al: Tamarindus indica (Cesalpiniaceae), and Syzygium cumini (Myrtaceae) seed extracts can kill multidrug resistant Streptococcus mutans in biofilm. J Nat Med. 2013; 13(2): 81-94.

Reference Source

Patwardhan B, Mutalik G, Tillu G: Integrative approaches for health: biomedical research, ayurveda and yoga. Academic Press (Chapter 9), 2015; 241-242. Publisher Full Text

Prakash S, Shelke AU: Role of Triphala in dentistry. J Indian Soc Periodontol. 2014; 18(2): 132-5.

PubMed Abstract | Publisher Full Text | Free Full Text

Sarvaiya N, Kothari V: Audible Sound in Form of Music Can Influence Microbial Growth, Metabolism and Antibiotic Susceptibility. J Appl Biotechnol Bioeng. 2017; 2(6): 212-219.

Publisher Full Text

Singh BR: Multiple-herbal-antimicrobial-resistance (MHAR) in microbes of animals, birds, fish, food, lizard and water origin. In Proceedings of International conference and 28th Annual convention of IAVMI-2014 on Challenges and opportunities in animal health at the face of globalization and climate change, Department of Veterinary Microbiology and Immunology, DUVASU, Mathura, India. 2014; 1: 26-29.

Reference Source

Singh S, Singh SK, Chowdhury I, et al:: Understanding the Mechanism of Bacterial Biofilms Resistance to Antimicrobial Agents. Open Microbiol J. 2017 11: 53-62.

PubMed Abstract | Publisher Full Text | Free Full Text

Trafny EA, Lewandowski R, Zawistowska-Marciniak I, et al.: Use of MTT assay for determination of the biofilm formation capacity of microorganisms in metalworking fluids. World J Microbiol Biotechnol. 2013; 29(9): 1635-1643. PubMed Abstract | Publisher Full Text

Wipperman MF, Fitzgerald DW, Juste MAJ, et al: Antibiotic treatment for Tuberculosis induces a profound dysbiosis of the microbiome that persists long after therapy is completed. Sci Rep. 2017; 7(1): 10767.

PubMed Abstract | Publisher Full Text | Free Full Text

Zatorska B, Arciola CR, Haffner N, et al.: Bacterial Extracellular DNA Production Is Associated with Outcome of Prosthetic Joint Infections. Biomed Res Int. 2018; 2018: 1067413.

PubMed Abstract | Publisher Full Text | Free Full Text 


\section{Open Peer Review}

\section{Current Peer Review Status: ? ?}

\section{Version 1}

Reviewer Report 02 September 2020

https://doi.org/10.5256/f1000research.21707.r56187

(C) 2020 Almeida F. This is an open access peer review report distributed under the terms of the Creative Commons Attribution License, which permits unrestricted use, distribution, and reproduction in any medium, provided the original work is properly cited.

\section{Felipe Alves de Almeida}

Department of Nutrition, Federal University of Juiz de Fora (UFJF), Governador Valadares, Brazil

The article is interesting, but some adjustments are needed. Initially, the quality of the figures should be improved. One point that concerns me is the interpretations of the results of the in vitro experiments, because when the concentration of TF influences the growth of bacteria, nothing can be said about its anti-quorum sensing effect. The other comments are marked in a document in PDF format which can be found here.

Is the work clearly and accurately presented and does it cite the current literature? Yes

Is the study design appropriate and is the work technically sound? Yes

Are sufficient details of methods and analysis provided to allow replication by others? Yes

If applicable, is the statistical analysis and its interpretation appropriate? Yes

Are all the source data underlying the results available to ensure full reproducibility? Yes

Are the conclusions drawn adequately supported by the results? Partly

Competing Interests: No competing interests were disclosed.

Reviewer Expertise: Microbiology. 


\section{I confirm that I have read this submission and believe that I have an appropriate level of expertise to confirm that it is of an acceptable scientific standard, however I have significant reservations, as outlined above.}

Author Response 18 Sep 2020

Vijay Kothari, Nirma University, Ahmedabad, India

\section{Response to Referees}

We thank both the referees for devoting their valued time in reviewing our manuscript. Our comment-wise response to their comments is as under:

\section{Response to general comments from Dr. Felipe Alves de Almeida:}

1. Quality of the figures: We have set the resolution of all figures at $1000 \mathrm{dpi}$ (which also satisfies journal's criteria of minimum $600 \mathrm{dpi}$ ), and are unable to improve them further.

2. The referee has pointed to a very logical issue with respect to interpretation of the in vitro results that if the test formulation affects bacterial growth, then how can we judge its effect on pigment production as quorum-modulatory effect?

To safeguard against this, we have already plotted 'Pigment Unit', and not the absolute pigment OD. 'Pigment Unit' are OD of pigment divided by cell density. Since this is a quantification of pigment produced per unit of growth, it nullifies any variation in pigment production due to changes in cell density in experimental vs. control tubes. Calculation of these 'Pigment Units' for individual pigments has already been mentioned in the legend of Figure-8. To further clarify this point, we have added this sentence to the figure-8 legend: "Pigment Units were calculated to nullify the effect of any change in cell density on pigment production".

On the same line, for other in vitro assays too (e.g. lysozyme susceptibility, haemolysis assay, etc.), before performing the assay we had equalized cell density of the control and experimental cultures, to ensure that TF's effect (if any) on bacterial growth does not interfere with interpretation of our results. This OD equalization step has already been mentioned in the 'Methods' section.

\section{Response to comments from Dr. Felipe Alves de Almeida marked within the annotated manuscript:}

1. The referee has asked for why have we chosen $750 \mathrm{~nm}$ for quantifying cell density. Please note that the bacteria being studied here are pigmented ones, and their pigments can interfere in measuring cell density within the visible range of spectrum (400-700 nm). In our earlier study [Joshi et al. (2016); DOI:

$10.2174 / 1872208310666160414102848$; which we have already cited in the current paper], we have shown $764 \mathrm{~nm}$ as the more appropriate one for quantifying cell density of pigmented bacteria, as compared to the conventionally used wavelengths e.g. $600 \mathrm{~nm}$. Since the wavelength nearest to $764 \mathrm{~nm}$ available in the instrument used by us was $750 \mathrm{~nm}$, we used that. We had earlier also confirmed that OD of the bacterial suspension used by us do not statistically differ at $764 \mathrm{~nm}$ vs. $750 \mathrm{~nm}$. 
Appropriateness of $764 \mathrm{~nm}$ for studying $C$. violaceum has also been reported by Gallardo et al. AMB Express 2014, 4:4 [http://www.amb-express.com/content/4/1/4].

2. In the 'Results' section under 'in vivo assays', the referee has raised a question that why different concentrations of TF used for pathogens. In response to that we would like to state that all pathogens were challenged with identical concentrations of TF in the range of $0.5-100$ microgram $/ \mathrm{mL}$. However in figures corresponding to these results, we have showed only non-overlapping lines. Data regarding other concentrations has been mentioned in the figure legends. If we include lines pertaining to all concentrations in the graph, then it becomes very fuzzy and difficult to understand.

3. Though referee's suggestion of merging Figure-2 with Figure-1 is fully logical, we are unable to implement it, as that will cause multiple lines in Figure-1 to overlap making it fuzzy and difficult to understand. For the same reason, we were not able to put lines for all TF concentrations in the graphs of Figure-1, and had to include that data in figure legend.

4. Referee has suggested for including the details of Post-Extract Effect (PEE) in 'Method' section. However that was not done as the method is not different than that described for 'anti-infective assay' except that in the PEE assay the host worm was challenged with daughter cells of the TF-treated parent cells; and this small piece of information has already been mentioned in the 'Results' section while first mentioning PEE.

5. The referee has asked for data of PEE against $C$. violaceum. However PEE assay was done only with the pathogenic bacteria which are considered as serious threats, i.e. whose pathogenic/ antibiotic-resistant strains are listed as priority pathogens by $\mathrm{CDC} / \mathrm{WHO}$.

6. The referee has raised a query about the difference in survival \% of unchallenged/ unfed worms between figure 5 and figure 6 . It should be noted that prior to the prophylactic assay, whose results are depicted in Figure-5, worms were kept unfed for 5 days; whereas prior to longevity assay (results depicted in Figure-6) the worms were kept unfed for 3 days. Hence this additional 2-dyas of non-availability of food in the prophylactic assay explains lower survival of worms in 'control' wells in Figure-5.

7. As suggested by the referee, we have replaced 'Triphala formulation' with 'TF' at multiple places. Similarly at many places, he has suggested removal of parentheses, that has also been implemented.

8. Figure-8 has been revised as per his suggestion.

9. Figure-10: Referee has raised query about accuracy of the \% values. We thank him for his fine observation, as investigating this has made us locate errors in some $\%$ values as well as bar heights. All those errors have been corrected, and we are submitting revised figure.

10. All other minor corrections/ modifications marked by the referee in the PDF file have also been either implemented, OR we have provided appropriate response/ explanation by inserting 'comments' in the word file of revised version.

We hope that the revised version along with clarifications provided by us will be able to earn referee's and editor's approval. 
Competing Interests: None

Reviewer Report 15 August 2019

https://doi.org/10.5256/f1000research.21707.r51849

(C) 2019 Pattanayak S. This is an open access peer review report distributed under the terms of the Creative Commons Attribution License, which permits unrestricted use, distribution, and reproduction in any medium, provided the original work is properly cited.

\section{Shibabrata Pattanayak}

ARD (Vet. Research \& Investigation), Government of West Bengal, Kolkata, West Bengal, India

\section{Following remarks are to be considered.}

\section{A.Test formulation}

Triphala formulation (TF) (Emami Ltd; batch no. EM0029; Proportion of 3 constituent plant species: 1:1:1) was purchased from a local market. For assay purpose, $150 \mathrm{mg}$ of this formulation was suspended in $5 \mathrm{ml}$ of DMSO (Merck, Mumbai), followed by vortexing for $15 \mathrm{~min}$. Then it was centrifuged at 8,000 rpm for $30 \mathrm{~min}$ at ambient temperature, and resulting supernatant was collected in a sterile glass vial ( $15 \mathrm{ml}$; Borosil) and stored under refrigeration till further use. Remaining pellet was subjected to drying in an oven at $70-80^{\circ} \mathrm{C}$ until the solvent was completely evaporated, followed by weighing of the dried plant material. Subtracting the latter from the initial weight of $150 \mathrm{mg}$, the concentration of test formulation in supernatant was calculated to be 22.94 $\mathrm{mg} / \mathrm{ml}$. This way the whole formulation was found to contain $70 \%$ DMSO soluble fraction, which was used for our experiments.

\section{Remark}

DMSO is having some effect on at least some microorganisms. What concentration of DMSO was used? Please add report / reference of non - germicidal effect of DMSO at the concentration used in your experiment.

You may consult the following articles:

1. Kirkwood ZI, Millar BC, Downey DG, Moore JE. Antimicrobial effect of dimethyl sulfoxide and $\mathrm{N}, \mathrm{N}$ - Dimethylformamide on Mycobacterium abscessus: Implications for antimicrobial susceptibility testing. Int J Mycobacteriol 2018;7:134-136.

2. Mi H, Wang D, Xue Y, Zhang Z, Niu J, Hong Y, Drlica K, Zhao X. 2016. Dimethyl sulfoxide protects Escherichia coli from rapid antimicrobial-mediated killing. Antimicrob Agents Chemother 60:5054 -5058. doi:10.1128/AAC.03003-15. ${ }^{2}$

3. Ashraf S. Hassan (2014) The Antibacterial Activity of Dimethyl Sulfoxide (DMSO) with and without of Some Ligand Complexes of the Transitional Metal Ions of Ethyl Coumarin against Bacteria Isolate from Burn and Wound Infection. Journal of Natural Sciences Research. 
Vol.4, No.19, 106-111. ${ }^{3}$

4. Howard C. Ansel, William P. Norred, Ivan L. Roth (1969) Antimicrobial activity of dimethyl sulfoxide against Escherichia coli, Pseudomonas aeruginosa, and Bacillus megaterium. J Pharmaceutical sciences 58(7): 836-839. ${ }^{4}$

B. Some portions are appeared unclear. Please modify the sentences:

\section{Page 2, Column 2 Paragraph 4.}

Prophylactic assay (Patel et al., 2018b): ......These worms were then fed with TF by mixing required concentration of this formulation $(100 \mu \mathrm{L})$ with $\mathrm{M} 9$ medium $(800 \mu \mathrm{L})$ and placed in a 24-well plate (non-treated polystyrene plates....

Remark:

Is it the DMSO -TRIFALA mixed supernatant?

\section{Page 4 Column 1 Paragraph 4.}

......at par with that of control (DMSO treated parent culture). -

Remark:

Point is not clear.

\section{Overall Comment:}

The research work is very good. The writing style is also good. After the mentioned modifications, the article may be accepted.

\section{References}

1. Kirkwood ZI, Millar BC, Downey DG, Moore JE: Antimicrobial effect of dimethyl sulfoxide and N, $\mathrm{N}$-Dimethylformamide on Mycobacterium abscessus: Implications for antimicrobial susceptibility testing.Int J Mycobacteriol. 7 (2): 134-136 PubMed Abstract | Publisher Full Text

2. Mi H, Wang D, Xue Y, Zhang Z, et al.: Dimethyl Sulfoxide Protects Escherichia coli from Rapid Antimicrobial-Mediated Killing.Antimicrob Agents Chemother. 60 (8): 5054-8 PubMed Abstract |

Publisher Full Text

3. Hassan AS: The Antibacterial Activity of Dimethyl Sulfoxide (DMSO) with and without of Some Ligand Complexes of the Transitional Metal Ions of Ethyl Coumarin against Bacteria Isolate from Burn and Wound Infection.Journal of Natural Sciences Research. 2014; 4 (19): 106-111

4. Ansel HC, Norred WP, Roth IL: Antimicrobial activity of dimethyl sulfoxide against Escherichia coli, Pseudomonas aeruginosa, and Bacillus megaterium.J Pharm Sci. 1969; 58 (7): 836-9 PubMed Abstract | Publisher Full Text

Is the work clearly and accurately presented and does it cite the current literature? Partly

Is the study design appropriate and is the work technically sound? 
Partly

Are sufficient details of methods and analysis provided to allow replication by others? Yes

If applicable, is the statistical analysis and its interpretation appropriate?

I cannot comment. A qualified statistician is required.

Are all the source data underlying the results available to ensure full reproducibility?

Yes

Are the conclusions drawn adequately supported by the results?

Yes

Competing Interests: No competing interests were disclosed.

Reviewer Expertise: Ethno- Pharmacology, Immunology, Bacteriology, Virology, Biochemistry

I confirm that I have read this submission and believe that I have an appropriate level of expertise to confirm that it is of an acceptable scientific standard, however I have significant reservations, as outlined above.

Author Response 18 Sep 2020

Vijay Kothari, Nirma University, Ahmedabad, India

We thank both the referees for devoting their valued time in reviewing our manuscript. Our comment-wise response to their comments is as under:

Response to comments from Dr. S Pattanayak:

1. DMSO was used in our experiments at $0.5 \% \mathrm{v} / \mathrm{v}$. This information along with the fact that this much DMSO did not affect growth / pigment production / virulence of the bacterial strains employed in this study has already been there in legends of all the figures. For example, absence of in vitro effect of DMSO on growth and pigment production has been reported in legend of Figure-8. Legend of Figure-1 includes the statement that DMSO $(0.5 \% \mathrm{v} / \mathrm{v})$ affected neither bacterial virulence, nor did it exert any toxicity toward the host worms.

Referee has very logically raised this concern, as DMSO at higher concentrations have been reported to affect bacterial growth by multiple researchers including our group [doi: 10.1016/S1995-7645(14)60233-9; ] and those cited in the referee report. However, since we have already included the 'vehicle control' in all our experiments; we did not cite any separate references for that. DMSO at the concentration $(0.5 \% \mathrm{v} / \mathrm{v})$ used in this study has earlier been reported by us to exert no effect on bacterial growth and pigment production: https://shodhganga.inflibnet.ac.in/bitstream/10603/245830/14/17_annexure.pdf

2. Yes, it is Triphala dissolved in DMSO, which was fed to the worm population during prophylactic assay. The sentence "These worms were then. " has been modified.

3. For the sake of brevity, we have modified the sentence: ". ...at par with .. Here 
what we could demonstrate is that effect of TF remains even on the 'daughter cells' of the TF-exposed 'parent bacterial cells'. It should be noted that these daughter cells themselves were never directly exposed to the test formulation, and still their virulence is attenuated owing to their parent population's exposure to TF. To make the concept of 'post-extract effect' (PEE) clear to the readers, we have already provided a link [https://doi.org/10.32388/359873] in the same paragraph, which takes the reader to the definition of PEE.

We hope that the revised version along with clarifications provided by us will be able to earn referee's and editor's approval.

Competing Interests: None

The benefits of publishing with F1000Research:

- Your article is published within days, with no editorial bias

- You can publish traditional articles, null/negative results, case reports, data notes and more

- The peer review process is transparent and collaborative

- Your article is indexed in PubMed after passing peer review

- Dedicated customer support at every stage

For pre-submission enquiries, contact research@f1000.com 